\title{
EFFECT OF PHOSPHOR FERTILIZER, MAGNETIC WATER AND HUMIC ACID ON THE GROWTH, PHOTOSYNTHESIS PIGMENTS AND OIL YIELD COMPONENTS OF Nigella sativa PLANT
}

\author{
Hadar S.Faizy
}

Department of Horticulture, College of Agricultural Engineering Sciences,

University of Duhok,, Kurdistan Region, Iraq.

E-mail:hadar.said@uod.ac

\begin{abstract}
Pots experiment was carried out in the greenhouse of Horticulture Department College of Agriculture Engineering Sciences/ University of Duhok to investigate the influence of three levels of $\mathrm{P}_{2} \mathrm{O}_{5}$ fertilizer $(0,260$ and $520 \mathrm{mg})$ per pot , humic acid at $\left(0,0.6\right.$ and $\left.0.8 \mathrm{mg} . \mathrm{L}^{-1}\right)$ and magnetic water with three group, group (1) irrigated with tap water, group (2) irrigated with magnetized water remain in the container for 12 hours and group (3) irrigated with magnetized water remain in the container for 24 hours on the growth and oil yield of Black cumin Nigella sativa $\mathrm{L}$. The experimental treatments consisted of five replications in Random Complete Block Design (RCBD). The results revealed that $\mathrm{P}_{2} \mathrm{O}_{5}$ fertilizer at $520 \mathrm{mg}$.pot ${ }^{-1}$ significantly increased all the studied characteristics. Humic acid at 0.6 and $0.8 \mathrm{mg} . \mathrm{L}^{-1} \mathrm{had}$ no significant effect on most of the studied characteristics except total chlorophyll and volatile oil. The group of plants that irrigated with magnetic water for $24 \mathrm{~h}$ caused significant increasing in all studied characteristics. Double and triple interactions among studies factors showed significant influence on all the studied characteristics as compared to untreated plants including (plant height, number of branches per plant, stem diameter, number of capsule/plant, dry weight, total chlorophyll, fixed oil percentage, volatile oil percentage and total carbohydrates percentage).
\end{abstract}

Key words: Black cumin, Humic acid, Magnetic water.

Received:19/3/2019 Accepted:10/10/2019

\section{INTRODUCTION}

One of the most important medicinal plants is Black cumin (Nigella sativa $\mathrm{L}$ ). It is an annual herbaceous plant belonging to the family Ranunculacea which grows in west Asia and Mediterranean region, it is one of the most studied plants extensively due to its importance in phytochemical and pharmaceutical aspects (Riaz et al., 1996).The plant acquired its Pharmacological activity and its medical value in great splendor and occupied a special place for medicinal plants in the Islamic civilization through the ideological belief in its treatment of multiple diseases the holy prophet, Mohammed (peace be upon him ) that the plant is Heals all sickness except death. (Ul-Hassan Gilani.,et al 2004). It has been used as a herbal medicine for more than 2000 years. It is also used as a food additive and flavor in many countries; it was used as natural remedies traditionally from ancient time may be from Assyrian civilization (Kamil, 2003). Traditionally the black seed and its oil show effectively range of antibacterial, antitumor, anorexia, antiinflammatory, fever, hypoglycemic, skin disease, muscle relaxant, cough and immune stimulant activities (Hosseinzadeh et al., 2007; and Buriro and Tayyab, 2007 and Shabnam et al., 2012). Researcher mentioned that most of these effects attributed to the essential and volatile oils of N.sativa plant seeds (Nickavar et al., 2003 and Gharby et al., 2014). It was also reported that high levels of nitrogen and 
phosphorus fertilizers $\left(280 \mathrm{~N}\right.$ and $260 \mathrm{P}_{2} \mathrm{O}_{5} \mathrm{~kg} \mathrm{ha}^{-1}$ ) caused significant increase in fixed oil, volatile oil, protein and phosphorus content in the seeds of Nigella sativa plant (Hammo, 2008). Al- Rubaye, (2009) concluded that providing nigella plants with foliar fertilizers during active vegetative growth increases yield significantly when compared with soil applied fertilizers.

Recently the use of physical methods for plant growth stimulation is getting more popular due to the less harmful influence on the environment. Moreover, magnetized water for irrigation is recommended to save irrigation water (Aladjadjiyan, 2007).

Magnetic water is considered one of several physical factors effects on plant growth and development. Magnetic water fields are known to induce biochemical changes and could be used as a stimulator for growth related reactions (Hameda and El-Sayed, 2014).

Magnetic Water plays important role in the growth of any plant. on the quality of water used is such as enhances the growth, good quality and quantity and good yield of plants (Mousavi 2011; Fard et al., 2011).The effects of magnetic treatment of irrigation water and snow pea (Pisum sativum L var. macrocarpon) and Kabuli chickpea Cicer arietinum L on the seeds emergence, early growth and nutrient contents of seedlings were investigated under glasshouse conditions the results showed that magnetic water led to a significant increase in emergence rate index $42 \%$ for snow pea and $51 \%$ for chickpea), shoot dry weight (25\% for snow pea and $20 \%$ for chickpea) and contents of N, K, Ca, Mg, S, Na, Zn, Fe and Mn in both seedling varieties compared to control seedlings Maheshwari and Grewal (2010). Also studied the changes in plants with seeds subjected to electric, magnetic or electromagnetic field. Effect of high voltage field on fruits like pineapple has also been studied Dastgheib et al.,(2013).

Effect of Magnetic water on chemical composition and nutrients on the Vicia faba, L. cv. Giza 3 plant the seeds of broad bean were irrigated with water passed through magnetic device is carried out by (Hameda and El Sayed, 2014), the results showed that magnetic water treatment enhanced the growth, chemical constituents such as chlorophyll a and b, carotenoids, total available carbohydrates, protein, total amino acids, total phenol, RNA,DNA, ) and inorganic minerals $\left(\mathrm{K}^{+}, \mathrm{Na}^{+}, \mathrm{Ca}^{+2}\right.$ and $\mathrm{P}^{+3}$ ) contents in all parts of broad bean plant

Humic acid is one of the novel materials when it applied to nutrient solution enhanced the growth of transplants also increased the minerals structure (David et $a l, 1994)$. It has efficiency in the growth of plants and the availability of the elements, the using of humic acid even though with little concentration lead to increase permeability of the cellular membrane (Solange and Rezende 2008). Humic acid promoted plant growth and induced soil microorganisms like bacteria and fungi and provide carbon as a source for the organism's humic acid as well acting as chelating good martial, (Leonard, 2008). Humic compounds are the most abundant of the complex ligands, which are found in nature. In this regard, it is well known that the humic compounds improve soil structure, increase soil microbial population, increase soil cation exchange capacity and providing some specific materials for plant root indirectly by providing macro and micro minerals, leading 
to the increase of soil fertility (Rizal et al.,2010). Similar to these results Gad ElHak et al., (2012) obtained that foliar application of pea plants with humic acid is very beneficial to the crop growth and yield.

This study was done to clarify the influence of phosphor fertilizers, magnetic water and humic acid on vegetative, reproductive growth, photosynthesis pigments and seeds oil yield of Nigella sativa plant.

\section{MATERIALS AND METHODS}

Pots experiment was conducted at 2013 in greenhouse of Horticulture department /college of Agriculture Engineering Sciences /University of Duhok to investigate the effect of some agricultural factors on vegetative growth and oil seed yield of Nigella sativa L. The seeds which were bought from the herbal market of Duhok city were cultivated in $15^{\text {th }}$ Oct 2013 sowed handily in with $(15 \mathrm{~cm})$ diameter were filled with soil that analyzed physically and chemically in the laboratory of soil department, as showed in (Table 1). The plants were fertilized with three level of phosphor $(0,260$ and $260 \mathrm{mg}) \mathrm{P}_{2} \mathrm{O}_{5}$ per pot added to the plants after 3 to 4 pairs of leaves were appeared. Humic acid at three concentrations ( 0 and 0.6 and $0.8 \mathrm{mg} . \mathrm{L}^{-1}$ ) were sprayed after one month of planting by three times within ten days intervals. The plants were watered with magnetized water was prepared by passing through a pair of strong permanent magnets disk (0.32T) with opposite polarity created in the Physics department college of science in Duhok University without side effects. Which positioned outside polymer container in opposite pole configuration. Three groups were used, group (1) irrigated with tap water, group (2) irrigated with magnetized water remain in the container for 12 hours and group (3) irrigated with magnetized water remain in the container for 24 hours, to check if the water is magnetized or not a simple test was done cardboard was placed over a pair of strong permanent magnets then few drops of magnetized water were poured on cardboard exactly above the magnets. The water if properly magnetized stayed in a circular form whereas normal water failed to stay. Weeds were removed by hand and all agriculture practices were done as needed. Harvesting was done on $15^{\text {th }}$ June 2013 manually by pulling the dry plants out of the soil.

Experimental measurements concluded some vegetative growth (high of plant, stem diameter, number of branch per plant, number of capsule per plant, and dry weight vegetative growth and some photosynthesis pigments, oil yield of seeds and total carbohydrate.

Fixed oil percentage measurement according to (A,O,A,C,2000), volatile oil percentage measurement according to British pharmacopeia, (Ggrainger, 1968) which was mentioned by (Ranganna,1986), total carbohydrate measurement according to Herbert et al. (1971) using the Spectra photometer .

Table (1): Physical and chemical properties of soil.

\begin{tabular}{|c|c|c|c|c|c|c|}
\hline $\mathrm{N} \%$ & $\mathrm{P} \%$ & $\mathrm{~K} \%$ & $\mathrm{EC}$ mmhos/cm & $\mathrm{pH}$ & Organic matter \% & $\mathrm{CaCO}_{3} \%$ \\
\hline 0.023 & 0.008 & 0.084 & 1.8 & 7.64 & 1.08 & 24.04 \\
\hline Clay \% & Sand \% & \multicolumn{3}{|c|}{ Silt } & \multicolumn{2}{c|}{ Texture } \\
\hline 16.93 & 58.62 & 23.0 & \multicolumn{3}{c|}{ Sandy Silt } \\
\hline
\end{tabular}


All measured Characters were subjected to variance analysis. And all data obtained were analyzed and compared statistically at a significance level of 5\%, using SAS program (SAS, 2007).

Vegetative Growth Trails.

\section{RESULTS AND DISCUSION}

Height of plant. (cm).

The results in Table (2) indicated that $\mathrm{P}_{2} \mathrm{O}_{5}$ fertilizer at $520 \mathrm{mg}^{-p^{-1}}$ significantly increased the height of plant $(58.82 \mathrm{~cm})$ compared to $(45.18 \mathrm{~cm})$ at $0 \mathrm{mg}^{-}$pot $^{-1} \mathrm{P}_{2} \mathrm{O}_{5}$, also mentioned that the effect of magnetic water represented was significantly increased the height of plants to $(59.03 \mathrm{~cm})$ in compression with untreated plant was $(53.98 \mathrm{~cm})$.while the height of plant had no significant effect when treated with humic acid the values were $(56.86,56.61$ and $56.82 \mathrm{~cm}$ ) respectively for $0,0.6,0.8$ mg. $\mathrm{L}^{-1}$ concentration. The interaction between $\mathrm{P}_{2} \mathrm{O}_{5}$ at $520 \mathrm{mg}$.pot ${ }^{-1}$ and magnetic water with $24 \mathrm{~h}$ gave the highest plants $(61.08 \mathrm{~cm})$ as compared to untreated $(51.40 \mathrm{~cm})$. On the other hand there was no significant effect on the high of plants when $\mathrm{p}_{2} \mathrm{O}_{5}$ with H.A used. The interaction between $\mathrm{P}_{2} \mathrm{O}_{5}$ fertilizer and humic acid showed significant differs when $\mathrm{P}_{2} \mathrm{O}_{5}$ fertilizer at $520 \mathrm{mg}$ pot $^{-1}$ with all concentrations of humic acid $(58.89,58.70$ and $56.87 \mathrm{~cm})$ respectively as compared to $(53.88 \mathrm{~cm})$ when treated with $\mathrm{P}_{2} \mathrm{O}_{5} 0 \mathrm{mg}$.pot ${ }^{-1}$ fertilizer combined with $0.6 \mathrm{mg} . \mathrm{L}^{-1}$. The same table showed that applying humic acid at all concentration interacted with magnetic water treatments effected on the height of plant significantly $(59.07,59.03$ and $58.98 \mathrm{~cm})$ respectively comparing to the untreated plants $(54.06,53.77$ and $54.11 \mathrm{~cm})$. The triple interaction among $\mathrm{p}_{2} \mathrm{O}_{5}$ at $520 \mathrm{mg} \cdot$ pot $^{-1}$. magnetic water with $24 \mathrm{~h}$ and humic acid at 0,0.6 and 0.8 mg. $\mathrm{L}^{-1}$ obtained the best values included $(61.10,61.12$ and $61.03 \mathrm{~cm})$ respectively when compared with $0 \mathrm{mg}$.pot ${ }^{-1}$ of $\mathrm{P}_{2} \mathrm{O}_{5}$, magnetic water with humic acid ${ }^{1}(51.56$, 51.04 , and $51.60 \mathrm{~cm}$ ) respectively.

Number of Branches (branch.Plant ${ }^{-1}$ ).

Table (3) showed that $\mathrm{P}_{2} \mathrm{O}_{5}$ at $520 \mathrm{mg}$. pot $^{-1}$ concentration gave the highest number of branches ( 7.88 branch. Plant $\left.{ }^{-\mathbf{1}}\right)$ as compared to $\left(7.18\right.$ branch. Plant $\left.^{\mathbf{- 1}}\right)$ with treated plants. The highest number of branches was noticed when the plants irrigated with magnetic water for $24 \mathrm{~h}$ it was (7.89 branch. Plant $\left.{ }^{-1}\right)$ as compared to the plants that irrigated by tap water $\left(7.08\right.$ branch.Plant $\left.^{\mathbf{- 1}}\right)$. While there are no significant effect appeared when the treated with humic acid at all concentrations. The interaction between $\mathrm{P}_{2} \mathrm{O}_{5}$ at mg. pot $^{-1}$ and magnetic water with $24 \mathrm{~h}$ gave the highest value of branches number (8.24 branche. Plant $\left.{ }^{-1}\right)$ as compared to (6.72 branch.Plant ${ }^{-1}$ ) with untreated plants. While there was significant effect on the number of branches when $\mathrm{P}_{2} \mathrm{O}_{5}$ at $520 \mathrm{mg}$. pot ${ }^{-1}$ with humic acid at all concentrations (7.85,7.89 and 7.90 branch.Plant $\left.{ }^{-1}\right)$ respectively as compared to $(7.19,7.14$ and 7.20 branch. Plant ${ }^{-1}$ ) respectively for $\mathrm{P}_{2} \mathrm{O}_{5}$ at $0 \mathrm{mg}$. pot $^{-1}$ interacted with all humic acid concentrations. The same table showed that adding humic acid at all concentrations interacted with magnetic water $24 \mathrm{~h}$ significantly differs $(7.85,7.86$ and 7.98 branch. Plant ${ }^{-1}$ ) as compared to $(7.06,7.12$ and 7.20 branch. Plant) at magnetic water $0 \mathrm{~h}$ interacted with humic acid at all concentrations. Regarding to the triple 
interaction among $\mathrm{P}_{2} \mathrm{O}_{5}$ at $520 \mathrm{mg}$. pot ${ }^{-1}$, magnetic water $24 \mathrm{~h}$ and humic acid at all concentrations gave the significant value $\left(8.17,8.22\right.$ and 8.32 branch. plant $\left.{ }^{1}\right)$ in comparison with lowest value obtained from the interaction of $0 \mathrm{mg}$. pot ${ }^{-1}$ of $_{2} \mathrm{p}_{2}$ ,magnetic water $0 \mathrm{~h}$ and humic acid at all concentrations (6.73.6.73 and 6.70 branch.plant ${ }^{-1}$ ) respectively.

Table (2): Effect of phosphor fertilizer, magnetic water and humic acid on the hight of Nigella sativus plant (cm).

\begin{tabular}{|c|c|c|c|c|c|c|}
\hline \multirow{2}{*}{$\begin{array}{c}\mathrm{P}_{2} \mathrm{O}_{5} \\
\left(\mathrm{mg} \cdot \text { pot }^{-1}\right)\end{array}$} & \multirow{2}{*}{$\begin{array}{l}\text { Magnetic } \\
\text { water } \\
\text { (hours) }\end{array}$} & \multicolumn{3}{|c|}{ Humic acid $\left(\mathrm{mg} \cdot \mathrm{L}^{-1}\right)$} & \multirow{2}{*}{$\begin{array}{c}\mathrm{P}_{2} \mathrm{O}_{5} \\
\times \\
\text { Magnetic } \\
\text { water }\end{array}$} & \multirow{2}{*}{$\begin{array}{l}\mathrm{P}_{2} \mathrm{O}_{5} \\
\text { effect }\end{array}$} \\
\hline & & 0 & 0.6 & 0.8 & & \\
\hline \multirow[t]{3}{*}{0} & 0 & $51.56 f$ & $51.04 \mathrm{f}$ & $51.60 \mathrm{f}$ & $51.40 \mathrm{f}$ & \multirow[t]{3}{*}{$54.18 \mathrm{c}$} \\
\hline & $12 \mathrm{~h}$ & $54.95 \mathrm{e}$ & $54.29 \mathrm{e}$ & $54.86 \mathrm{e}$ & $54.70 \mathrm{e}$ & \\
\hline & $24 \mathrm{~h}$ & $56.57 \mathrm{~d}$ & $56.30 \mathrm{~d}$ & $56.47 \mathrm{~d}$ & $56.45 d$ & \\
\hline \multirow[t]{3}{*}{260} & 0 & $54.53 \mathrm{e}$ & $54.42 \mathrm{e}$ & $54.57 \mathrm{e}$ & $54.50 \mathrm{e}$ & \multirow[t]{3}{*}{$57.29 \mathrm{~b}$} \\
\hline & $12 \mathrm{~h}$ & $57.92 \mathrm{c}$ & $57.67 \mathrm{c}$ & $57.83 \mathrm{c}$ & $5.88 \mathrm{c}$ & \\
\hline & $24 \mathrm{~h}$ & $59.54 b$ & $59.68 b$ & $59.44 b$ & $59.55 \mathrm{~b}$ & \\
\hline \multirow[t]{3}{*}{520} & 0 & $\begin{array}{c}56.09 \\
\mathrm{~d}\end{array}$ & $55.86 \mathrm{~d}$ & $56.16 \mathrm{~d}$ & $56.03 \mathrm{~d}$ & \multirow[t]{3}{*}{$58.82 \mathrm{a}$} \\
\hline & $12 \mathrm{~h}$ & $59.48 b$ & $59.11 b$ & $59.42 b$ & $59.34 \mathrm{~b}$ & \\
\hline & $24 \mathrm{~h}$ & $61.10 \mathrm{a}$ & $61.12 \mathrm{a}$ & $61.03 a$ & $61.08 \mathrm{a}$ & \\
\hline \multirow{3}{*}{$\begin{aligned} & \mathrm{P}_{2} \mathrm{O}_{5} \\
\times & \text { Humic } \\
& \text { acid }\end{aligned}$} & 0 & $54.36 \mathrm{c}$ & $53.88 \mathrm{~d}$ & $54.31 \mathrm{c}$ & \multirow{3}{*}{\multicolumn{2}{|c|}{$\begin{array}{c}\text { Magnetic water } \\
\text { effect }\end{array}$}} \\
\hline & 260 & $57.33 b$ & $57.26 \mathrm{~b}$ & $57.28 b$ & & \\
\hline & 520 & $58.89 \mathrm{a}$ & $58.70 \mathrm{a}$ & $58.87 \mathrm{a}$ & & \\
\hline \multirow{3}{*}{$\begin{array}{l}\text { Magnetic } \\
\text { water } \\
\times \text { Humic } \\
\text { acid }\end{array}$} & 0 & $54.06 \mathrm{c}$ & $53.77 \mathrm{c}$ & $54.11 \mathrm{c}$ & \multicolumn{2}{|r|}{$53.98 \mathrm{c}$} \\
\hline & $12 \mathrm{~h}$ & $57.45 b$ & $57.03 \mathrm{~b}$ & $57.37 \mathrm{~b}$ & \multicolumn{2}{|r|}{$57.28 \mathrm{~b}$} \\
\hline & $24 \mathrm{~h}$ & $59.07 \mathrm{a}$ & $59.03 a$ & $58.98 \mathrm{a}$ & \multicolumn{2}{|r|}{$59.03 \mathrm{a}$} \\
\hline \multicolumn{2}{|c|}{ Humic acid effect } & $56.86 \mathrm{a}$ & $56.61 \mathrm{a}$ & $56.82 \mathrm{a}$ & & \\
\hline
\end{tabular}

*Means followed by the same letter for each factor and interaction do not differ significantly from each other's according to Duncan's Multiple range Test at 5\% level. 
Table (3): Effect of phosphor fertilizer, magnetic water and humic acid on the branches number of Nigella sativus plant (branch.plant ${ }^{-1}$ ).

\begin{tabular}{|c|c|c|c|c|c|c|}
\hline \multirow{2}{*}{$\begin{array}{c}\mathrm{P}_{2} \mathrm{O}_{5} \\
\left(\mathrm{mg} \cdot \text { pot }^{-1}\right)\end{array}$} & \multirow{2}{*}{$\begin{array}{l}\text { Magnetic } \\
\text { water } \\
\text { (hours) }\end{array}$} & \multicolumn{3}{|c|}{ Humic acid $\left(\mathrm{mg} . \mathrm{L}^{-1}\right)$} & \multirow{2}{*}{$\begin{array}{c}\mathrm{P}_{2} \mathrm{O}_{5} \\
\times \\
\text { Magnetic } \\
\text { water }\end{array}$} & \multirow{2}{*}{$\begin{array}{l}\mathrm{P}_{2} \mathrm{O}_{5} \\
\text { effect }\end{array}$} \\
\hline & & 0 & 0.6 & 0.8 & & \\
\hline \multirow[t]{3}{*}{0} & 0 & $6.73 \mathrm{k}$ & $6.73 \mathrm{k}$ & $6.70 \mathrm{k}$ & $6.72 \mathrm{~g}$ & \multirow[t]{3}{*}{$7.18 \mathrm{c}$} \\
\hline & $12 \mathrm{~h}$ & $7.34 \mathrm{~g}-\mathrm{j}$ & $7.21 \mathrm{~h}-\mathrm{j}$ & $7.28 \mathrm{~h}-\mathrm{j}$ & $7.28 \mathrm{e}$ & \\
\hline & $24 \mathrm{~h}$ & $7.51 \mathrm{f}-\mathrm{h}$ & $7.47 \mathrm{f}-\mathrm{i}$ & $7.62 \mathrm{e}-\mathrm{g}$ & $7.53 \mathrm{~cd}$ & \\
\hline \multirow[t]{3}{*}{260} & 0 & $7.08 \mathrm{j}$ & $7.14 \mathrm{ij}$ & $7.08 \mathrm{j}$ & $7.10 \mathrm{f}$ & \multirow[t]{3}{*}{$7.56 \mathrm{~b}$} \\
\hline & $12 \mathrm{~h}$ & $7.70 \mathrm{~d}-\mathrm{f}$ & $7.62 \mathrm{e}-\mathrm{g}$ & $7.65 \mathrm{e}-\mathrm{g}$ & $7.66 \mathrm{c}$ & \\
\hline & $24 \mathrm{~h}$ & $7.87 \mathrm{c}-\mathrm{e}$ & $7.88 \mathrm{c}-\mathrm{e}$ & $7.99 \mathrm{~b}-\mathrm{d}$ & $7.92 \mathrm{~b}$ & \\
\hline \multirow[t]{3}{*}{520} & 0 & $7.38 \mathrm{f}-\mathrm{j}$ & $7.48 \mathrm{f}-\mathrm{h}$ & $7.40 \mathrm{f}-\mathrm{j}$ & $7.42 \mathrm{~cd}$ & \multirow[t]{3}{*}{$7.88 \mathrm{a}$} \\
\hline & $12 \mathrm{~h}$ & $8.00 \mathrm{~b}-\mathrm{d}$ & $7.96 \mathrm{~b}-\mathrm{d}$ & $7.98 \mathrm{~b}-\mathrm{d}$ & $7.98 \mathrm{~b}$ & \\
\hline & $24 \mathrm{~h}$ & $8.17 \mathrm{bc}$ & $8.22 \mathrm{ab}$ & $8.32 \mathrm{a}$ & $8.24 \mathrm{a}$ & \\
\hline \multirow{3}{*}{$\begin{aligned} & \mathrm{P}_{2} \mathrm{O}_{5} \\
& \times \text { Humic } \\
& \text { acid }\end{aligned}$} & 0 & $7.19 \mathrm{c}$ & $7.14 \mathrm{c}$ & $7.20 \mathrm{c}$ & \multirow{3}{*}{\multicolumn{2}{|c|}{$\begin{array}{l}\text { Magnetic water } \\
\text { effect }\end{array}$}} \\
\hline & 260 & $7.55 \mathrm{~b}$ & $7.55 \mathrm{~b}$ & $7.58 \mathrm{~b}$ & & \\
\hline & 520 & $7.85 \mathrm{a}$ & $7.89 \mathrm{a}$ & $7.90 \mathrm{a}$ & & \\
\hline \multirow{3}{*}{$\begin{array}{l}\text { Magnetic } \\
\text { water } \\
\times \text { Humic } \\
\text { acid }\end{array}$} & 0 & $7.06 \mathrm{c}$ & $7.12 \mathrm{c}$ & $7.06 \mathrm{c}$ & \multicolumn{2}{|c|}{$7.08 \mathrm{c}$} \\
\hline & $12 \mathrm{~h}$ & $7.68 \mathrm{~b}$ & $7.60 \mathrm{~b}$ & $7.64 \mathrm{~b}$ & \multicolumn{2}{|c|}{$7.64 \mathrm{~b}$} \\
\hline & $24 \mathrm{~h}$ & $7.85 \mathrm{a}$ & $7.86 \mathrm{a}$ & $7.98 \mathrm{a}$ & \multicolumn{2}{|c|}{$7.89 \mathrm{a}$} \\
\hline \multicolumn{2}{|c|}{ Humic acid effect } & $7.53 \mathrm{a}$ & $7.52 \mathrm{a}$ & $7.56 \mathrm{a}$ & & \\
\hline
\end{tabular}

*Means followed by the same letter for each factor and interaction do not differ significantly from each other's according to Duncan's Multiple range Test at 5\% level.

Stem diameter $(\mathrm{mm})$.

The data in Table (4) recorded that significant effect appeared in stem diameter of the plants when $\mathrm{P}_{2} \mathrm{O}_{5} 520 \mathrm{mg}$. pot ${ }^{-1}$ concentration compared to untreated plants and the values respectively were $(5.24$ and $4.52 \mathrm{~mm})$.Irrigating the plants with magnetic water $24 \mathrm{~h}$ was significantly differed with the plans irrigated with 0 and $12 \mathrm{~h}$ tap water and they were respectively $(5.33,4.48 \mathrm{~mm}$ and 4.93$)$.The results also showed that all concentrations of humic acid do not have significant effect on steam diameter. Significant effect was observed with interaction between $\mathrm{P}_{2} \mathrm{O}_{5} 520 \mathrm{mg}$. pot $^{-1}$ and magnetic water $24 \mathrm{~h}$ gave $(5.65 \mathrm{~mm})$ as compared to $0 \mathrm{mg}$. pot $^{-1}(4.08$ $\mathrm{mm})$. The interaction between $\mathrm{P}_{2} \mathrm{O}_{5} 520 \mathrm{mg}$. pot ${ }^{-1}$ fertilizer with all concentrations of humic acid were significantly effected $(5.20,5.28$ and $5.23 \mathrm{~mm})$ respectively as compared to other treatments especially at $\mathrm{P}_{2} \mathrm{O}_{5} 0 \mathrm{mg}$. pot ${ }^{-1}$ for all the concentrations of humic acid the values were $(4.58,4.45$ and $4.52 \mathrm{~mm})$ respectively. The same direction was observed with interaction between humic acid at all concentration with magnetic water $24 \mathrm{~h}$ obtained significant effect on the stem diameter $(5.32,5.33$ and $5.34 \mathrm{~mm})$ compared to the untreated plants by magnetic water with all concentrations of humic acid $(4.49,4.50$ and $4.45 \mathrm{~mm})$ respectively. The triple interaction among the triple interaction among $\mathrm{P}_{2} \mathrm{O}_{5}$ at $520 \mathrm{mg}$. pot ${ }^{-1}$, 
magnetic water $24 \mathrm{~h}$ and humic acid at all concentrations obtained the highest values of stem diameter $(5.59,5.69$ and $5.66 \mathrm{~mm})$ compared to lowest values $(4.15,4.03$ and $4.06 \mathrm{~mm})$ respectively for $\mathrm{P}_{2} \mathrm{O}_{5}$ at $0 \mathrm{mg}$. pot ${ }^{-1}$, magnetic water $24 \mathrm{~h}$ and humic acid at all concentrations.

Table (4): Effect of phosphor fertilizer, magnetic water and humic acid on the stem diameter of Nigella sativus plant ( $\mathrm{mm}$ ).

\begin{tabular}{|c|c|c|c|c|c|c|}
\hline \multirow{2}{*}{$\begin{array}{c}\mathrm{P}_{2} \mathrm{O}_{5} \\
\left(\mathrm{mg} \cdot \text { pot }^{-1}\right)\end{array}$} & \multirow{2}{*}{$\begin{array}{l}\text { Magneti } \\
\text { c water } \\
\text { (hours) }\end{array}$} & \multicolumn{3}{|c|}{ Humic acid( $\left.\mathrm{mg} \cdot \mathrm{L}^{-1}\right)$} & \multirow{2}{*}{$\begin{array}{c}\mathrm{P}_{2} \mathrm{O}_{5} \\
\times \\
\text { Magnetic } \\
\text { water } \\
\end{array}$} & \multirow{2}{*}{$\begin{array}{l}\mathrm{P}_{2} \mathrm{O}_{5} \\
\text { Effect }\end{array}$} \\
\hline & & 0 & 0.6 & 0.8 & & \\
\hline \multirow[t]{3}{*}{0} & 0 & 4.151 & 4.031 & 4.061 & $4.08 \mathrm{~g}$ & \multirow{3}{*}{$4.52 \mathrm{c}$} \\
\hline & 12 & $4.61 \mathrm{i}-\mathrm{k}$ & $4.46 \mathrm{k}$ & $4.53 \mathrm{jk}$ & $4.54 \mathrm{f}$ & \\
\hline & 24 & $4.98 \mathrm{e}-\mathrm{h}$ & $4.87 \mathrm{i}-\mathrm{h}$ & $4.95 \mathrm{f}-\mathrm{h}$ & $4.93 \mathrm{de}$ & \\
\hline \multirow[t]{3}{*}{260} & 0 & $4.57 \mathrm{jk}$ & $4.60 \mathrm{i}-\mathrm{k}$ & 4.51 & $4.56 \mathrm{f}$ & \multirow[t]{3}{*}{$4.99 \mathrm{~b}$} \\
\hline & 12 & $5.03 \mathrm{~d}-\mathrm{h}$ & $5.03 \mathrm{~d}-\mathrm{h}$ & $4.98 \mathrm{e}-\mathrm{h}$ & $5.01 \mathrm{~d}$ & \\
\hline & 24 & $5.39 \mathrm{c}$ & $5.44 \mathrm{a}-\mathrm{c}$ & $5.40 \mathrm{bc}$ & $5.41 \mathrm{~b}$ & \\
\hline \multirow[t]{3}{*}{520} & 0 & $4.77 \mathrm{~h}-\mathrm{j}$ & $4.86 \mathrm{~g}-\mathrm{i}$ & $4.78 \mathrm{~h}-\mathrm{j}$ & $4.80 \mathrm{e}$ & \multirow[t]{3}{*}{$5.24 \mathrm{a}$} \\
\hline & 12 & $5.23 \mathrm{c}-\mathrm{f}$ & $5.29 \mathrm{~cd}$ & $5.24 \mathrm{c}-\mathrm{e}$ & $5.25 \mathrm{c}$ & \\
\hline & 24 & $5.59 \mathrm{ab}$ & $5.69 \mathrm{a}$ & $5.66 \mathrm{ab}$ & $5.65 \mathrm{a}$ & \\
\hline \multirow{3}{*}{$\begin{aligned} & \mathrm{P}_{2} \mathrm{O}_{5} \\
& \times \text { Humic } \\
& \text { acid }\end{aligned}$} & 0 & $4.58 \mathrm{c}$ & $4.45 \mathrm{c}$ & $4.52 \mathrm{c}$ & \multirow{3}{*}{\multicolumn{2}{|c|}{ M.W effect }} \\
\hline & 260 & $5.00 \mathrm{~b}$ & $5.02 \mathrm{~b}$ & $4.97 \mathrm{~b}$ & & \\
\hline & 520 & $5.20 \mathrm{a}$ & $5.28 \mathrm{a}$ & $5.23 \mathrm{a}$ & & \\
\hline \multirow{3}{*}{$\begin{array}{c}\text { Magnetic } \\
\text { water } \\
\times \text { Humic } \\
\text { acid }\end{array}$} & 0 & $4.49 \mathrm{c}$ & $4.50 \mathrm{c}$ & $4.45 \mathrm{c}$ & \multicolumn{2}{|c|}{$4.48 \mathrm{~b}$} \\
\hline & 12 & $4.95 \mathrm{~b}$ & $4.93 \mathrm{~b}$ & $4.92 \mathrm{~b}$ & \multicolumn{2}{|c|}{$4.93 \mathrm{~b}$} \\
\hline & 24 & $5.32 \mathrm{a}$ & $5.33 \mathrm{a}$ & $5.34 \mathrm{a}$ & \multicolumn{2}{|c|}{$5.33 \mathrm{a}$} \\
\hline \multicolumn{2}{|c|}{ Humic acid effect } & $4.92 \mathrm{a}$ & $4.92 \mathrm{a}$ & $4.90 \mathrm{a}$ & & \\
\hline
\end{tabular}

*Means followed by the same letter for each factor and interaction do not differ significantly from each other's according to Duncan's Multiple range Test at 5\% level.

Numberof capsules.pant ${ }^{-1}$

The data represented in Table (5) showed that $\mathrm{P}_{2} \mathrm{O}_{5}$ fertilizer at 520 mg.pot ${ }^{-1}$ had significant effect on the number of capsules (38.46 capsules. plant ${ }^{-1}$ ) compared to 0 and 260 mg.pot $^{-1}$ (34.40 and 36.46 capsules. plant ${ }^{-1}$ ). The plants that irrigated with magnetic water $24 \mathrm{~h}$ was significantly differed (38.70 capsules. plant ${ }^{-1)}$ with the plans that irrigated with 0 and $12 \mathrm{~h}$ magnetic water (33.70 and 37.42 capsules. plant ${ }^{-}$ ${ }^{1}$ ) respectively The results also showed that there is no significant effect for all concentrations of humic acid on number of capsules. Significant effect was obtained from the interaction between $\mathrm{P}_{2} \mathrm{O}_{5}$ at $520 \mathrm{mg}$.pot ${ }^{-1}$ and magnetic water with $24 \mathrm{~h}$ on number of capsules (40.63 capsules.plant ${ }^{-1}$ ) compared to untreated plants (34.40 capsules.plant ${ }^{-1}$ ).When $\mathrm{P}_{2} \mathrm{O}_{5}$ fertilizer at $520 \mathrm{mg}$ pot $^{-1}$ applied with all the concentrations of humic acid had significant effect (38.37,38.51 and 38.59 capsules.plant $\left.{ }^{-1}\right)$ respectively when compared to lowest values (34.23,34.37 and 
34.60 capsules.plant ${ }^{-1}$ ) respectively that obtained from $0 \mathrm{mg}$.pot ${ }^{-}$all concentrations of humic acid. The interaction between humic acid at all concentration with magnetic water with $24 \mathrm{~h}$ treatments have significant effect on the number of capsules $\left(38.49,38.68\right.$ and 38.94 capsule. $\left.^{\text {plant }}{ }^{-1}\right)$ as compared to the plants treated with $0 \mathrm{~h}$ magnetic water interacted with all concentrations of humic acid (33.50,33.51 and 33.43 capsule.plant $\left.{ }^{-1}\right)$ respectively. On the other hand the triple interaction among $\mathrm{P}_{2} \mathrm{O}_{5}$ at $520 \mathrm{mg}$. pot ${ }^{-1}$, magnetic water $24 \mathrm{~h}$ and humic acid at 0.6 and $0.8 \mathrm{mg} . \mathrm{L}^{-1}$ obtained the highest values of number of capsules (40.57 and 40.86 capsule.plant $\left.{ }^{-1}\right)$ compared to $\left(31.31,31.35\right.$ and 31.37 capsule.plant $\left.^{-1}\right)$ respectively 0 of $\mathrm{P}_{2} \mathrm{O}_{5}$ at $520 \mathrm{mg}$.pot ${ }^{-1}$, all concentration of humic acid and $0 \mathrm{~h}$ magnetic water.

Table (5): Effect of magnetic water, humic acid and phosphor fertilizer on the number of capsules of Nigella sativus plant (capsules.pant ${ }^{-1}$ ).

\begin{tabular}{|c|c|c|c|c|c|c|}
\hline \multirow{2}{*}{$\begin{array}{c}\mathrm{P}_{2} \mathrm{O}_{5} \\
\text { (mg.pot } \\
\text { (m) }\end{array}$} & \multirow{2}{*}{$\begin{array}{l}\text { Magnetic } \\
\text { water } \\
\text { (hours) }\end{array}$} & \multicolumn{3}{|c|}{ Humic acid $\left(\mathrm{mg} . \mathrm{L}^{-1}\right)$} & \multirow{2}{*}{$\begin{array}{c}\mathrm{P}_{2} \mathrm{O}_{5} \\
\times \\
\text { Magnetic } \\
\text { water }\end{array}$} & \multirow{2}{*}{$\begin{array}{l}\mathrm{P}_{2} \mathrm{O}_{5} \\
\text { effect }\end{array}$} \\
\hline & & 0 & 0.6 & 0.8 & & \\
\hline \multirow[t]{3}{*}{0} & 0 & $31.31 \mathrm{i}$ & $31.35 \mathrm{i}$ & $31.37 \mathrm{i}$ & $31.34 \mathrm{~g}$ & \multirow[t]{3}{*}{$34.40 \mathrm{c}$} \\
\hline & 12 & $35.07 \mathrm{~g}$ & $35.24 \mathrm{~g}$ & $35.55 \mathrm{fg}$ & $35.29 \mathrm{e}$ & \\
\hline & 24 & $36.31 \mathrm{ef}$ & $36.52 \mathrm{e}$ & $36.88 \mathrm{de}$ & $36.57 \mathrm{~d}$ & \\
\hline \multirow[t]{3}{*}{260} & 0 & $33.73 \mathrm{~h}$ & $33.78 \mathrm{~h}$ & $33.56 \mathrm{~h}$ & $33.69 \mathrm{f}$ & \multirow[t]{3}{*}{$36.74 \mathrm{~b}$} \\
\hline & 12 & $37.48 \mathrm{~cd}$ & $37.67 \mathrm{~cd}$ & $37.74 \mathrm{~b}$ & $37.63 \mathrm{c}$ & \\
\hline & 24 & $38.72 \mathrm{~b}$ & $38.95 \mathrm{~b}$ & $39.07 \mathrm{~b}$ & $38.91 \mathrm{~b}$ & \\
\hline \multirow[t]{3}{*}{520} & 0 & $35.46 \mathrm{fg}$ & $35.40 \mathrm{fg}$ & $35.36 \mathrm{~g}$ & $35.40 \mathrm{e}$ & \multirow[t]{3}{*}{$38.46 \mathrm{a}$} \\
\hline & 12 & $39.21 \mathrm{~b}$ & $39.29 \mathrm{~b}$ & $39.54 b$ & $39.35 \mathrm{~b}$ & \\
\hline & 24 & $40.45 \mathrm{~b}$ & $40.57 \mathrm{a}$ & $40.87 \mathrm{a}$ & $40.63 \mathrm{a}$ & \\
\hline \multirow{3}{*}{$\begin{array}{c}\mathrm{P}_{2} \mathrm{O}_{5} \\
\times \text { Humic } \\
\text { acid }\end{array}$} & 0 & $34.23 \mathrm{c}$ & $34.37 \mathrm{c}$ & $34.60 \mathrm{c}$ & \multirow{3}{*}{\multicolumn{2}{|c|}{$\begin{array}{l}\text { Magnetic water } \\
\text { effect }\end{array}$}} \\
\hline & 260 & $36.65 \mathrm{~b}$ & $36.80 \mathrm{~b}$ & $36.79 \mathrm{~b}$ & & \\
\hline & 520 & $38.37 \mathrm{a}$ & $38.42 \mathrm{a}$ & $38.59 \mathrm{a}$ & & \\
\hline \multirow{3}{*}{$\begin{array}{c}\text { Magnetic } \\
\text { water } \\
\times \text { Humic } \\
\text { acid }\end{array}$} & 0 & $33.50 \mathrm{c}$ & $33.51 \mathrm{c}$ & $33.43 \mathrm{c}$ & \multicolumn{2}{|c|}{$33.48 \mathrm{c}$} \\
\hline & 12 & $37.25 \mathrm{~b}$ & $37.40 \mathrm{~b}$ & $37.61 \mathrm{~b}$ & \multicolumn{2}{|c|}{$37.42 \mathrm{~b}$} \\
\hline & 24 & $38.49 \mathrm{a}$ & $38.68 \mathrm{a}$ & $38.94 \mathrm{a}$ & \multicolumn{2}{|c|}{$38.70 \mathrm{a}$} \\
\hline \multicolumn{2}{|c|}{ Humic acid effect } & $36.42 \mathrm{a}$ & $36.53 \mathrm{a}$ & $36.66 \mathrm{a}$ & & \\
\hline
\end{tabular}

*Means followed by the same letter for each factor and interaction do not differ significantly from each other's according to Duncan's Multiple range Test at 5\% level.

Dry weight of plant $(\mathrm{g})$.

Table (6) showed that $\mathrm{P}_{2} \mathrm{O}_{5}$ fertilizer at $520 \mathrm{mg} \cdot$ pot $^{-1}$ significantly increased the dry weight of plants $(7.205 \mathrm{~g})$ compared to 0 and $260 \mathrm{mg}^{\mathrm{pot}}{ }^{-1}(5.760 \mathrm{~g}$ and $6.309 \mathrm{~g}$ ). The plants which treated with magnetic water $24 \mathrm{~h}$ was significantly differed than that treated with 0 and $12 \mathrm{~h}$ magnetic water the values were (7.117, 5.746 and $6.411 \mathrm{~g}$ ) respectively. No significant differences appeared between all the concentrations of humic acid that used. The interaction between $\mathrm{P}_{2} \mathrm{O}_{5}$ fertilizer at $520 \mathrm{mg} \cdot$ pot $^{-1}$ and magnetic water for $24 \mathrm{~h}$ gave a significant effect on dry weight 
(7.939 g) as compared to other treatments especially untreated plants (5. 103g). Although all the humic acid concentrations of do not show significant effect compared to each other when it applied with $\mathrm{P}_{2} \mathrm{O}_{5}$ fertilizer at $520 \mathrm{mg}$. pot ${ }^{-1}$ on the dry weight of plant $(7.132,7.293$ and $7.190 \mathrm{~g})$ respectively, but they significantly differed with other treatments especially of $0 \mathrm{mg}^{-p^{-1}} \mathrm{P}_{2} \mathrm{O}_{5}$ and the values were respectively for all concentration of humic acid $(5.797,5.850$ and $5.634 \mathrm{~g})$. The data obtained that interaction between at humic acid 0 and $0.6 \mathrm{mg} \cdot \mathrm{L}^{-1}$ concentrations with magnetic water with $24 \mathrm{~h}$ treatment have significant effect on dry weight ( 7.190 and $7.214 \mathrm{~g}$ ) when compared to the lowest values obtained from $0 \mathrm{~h}$ magnetic water with all concentrations of humic acid (5.712,5.791 and 5.740 g) respectively. Significant values of dry weight were obtained when $(7.857,8.004$ and $7.957 \mathrm{~g})$ when $520 \mathrm{P}_{2} \mathrm{O}_{5}$ mg.pot ${ }^{-1}, 24 \mathrm{~h}$ magnetic water with all concentrations of humic acid as compared to other treatments especially when $0 \mathrm{P}_{2} \mathrm{O}_{5}$ mg.pot $^{-1}, 0 \mathrm{~h}$ magnetic water with all concentrations of humic acid (5.009, 5.138 and $5.073 \mathrm{~g})$ respectively.

Table (6): Effect of magnetic water, humic acid and phosphor fertilizer on the dry weight of Nigella sativus plant (g).

\begin{tabular}{|c|c|c|c|c|c|c|}
\hline \multirow{2}{*}{$\begin{array}{c}\mathrm{P}_{2} \mathrm{O}_{5} \\
\text { (mg.pot } \\
\text { 1) }\end{array}$} & \multirow{2}{*}{$\begin{array}{l}\text { Magnetic } \\
\text { water } \\
\text { (hours) }\end{array}$} & \multicolumn{3}{|c|}{ Humic $\operatorname{acid}\left(\mathrm{mg} . \mathrm{L}^{-1}\right)$} & \multirow{2}{*}{$\begin{array}{c}\mathrm{P}_{2} \mathrm{O}_{5} \\
\times \\
\text { Magnetic } \\
\text { water }\end{array}$} & \multirow{2}{*}{$\begin{array}{l}\mathrm{P}_{2} \mathrm{O}_{5} \\
\text { effect }\end{array}$} \\
\hline & & 0 & 0.6 & 0.8 & & \\
\hline \multirow[t]{3}{*}{0} & 0 & $5.009 \mathrm{~g}$ & $5.138 \mathrm{~g}$ & $5.073 \mathrm{~g}$ & $5.103 \mathrm{e}$ & \multirow[t]{3}{*}{$5.760 \mathrm{c}$} \\
\hline & 12 & $5.770 \mathrm{f}$ & $5.852 \mathrm{f}$ & $5.606 \mathrm{f}$ & $5.742 \mathrm{~d}$ & \\
\hline & 24 & $6.522 \mathrm{de}$ & $6.561 \mathrm{de}$ & $6.225 \mathrm{e}$ & $6.436 \mathrm{c}$ & \\
\hline \multirow[t]{3}{*}{260} & 0 & $5.605 \mathrm{f}$ & $5.654 \mathrm{f}$ & $5.593 \mathrm{f}$ & $5.617 \mathrm{~d}$ & \multirow[t]{3}{*}{$6.309 \mathrm{~b}$} \\
\hline & 12 & $6.276 \mathrm{e}$ & $6.368 \mathrm{e}$ & $6.126 \mathrm{e}$ & $6.360 \mathrm{~cd}$ & \\
\hline & 24 & $7.028 \mathrm{bc}$ & $7.077 \mathrm{bc}$ & $6.823 \mathrm{~cd}$ & $6.97 \mathrm{~b}$ & \\
\hline \multirow[t]{3}{*}{520} & 0 & $6.434 \mathrm{de}$ & $6.581 \mathrm{de}$ & $6.541 \mathrm{de}$ & $6.518 \mathrm{c}$ & \multirow[t]{3}{*}{$7.205 \mathrm{a}$} \\
\hline & 12 & $7.105 b c$ & $7.295 \mathrm{~b}$ & $7.074 b c$ & $7.168 \mathrm{~b}$ & \\
\hline & 24 & $7.857 \mathrm{a}$ & $8.004 \mathrm{a}$ & $7.957 \mathrm{a}$ & $7.939 \mathrm{a}$ & \\
\hline \multirow{3}{*}{$\begin{aligned} & \mathrm{P}_{2} \mathrm{O}_{5} \\
\times & \text { Humic } \\
& \text { acid }\end{aligned}$} & 0 & $5.797 \mathrm{~cd}$ & $5.850 \mathrm{c}$ & $5.635 \mathrm{~d}$ & \multirow{3}{*}{\multicolumn{2}{|c|}{$\begin{array}{c}\text { Magnetic water } \\
\text { effect }\end{array}$}} \\
\hline & 260 & $6.303 \mathrm{~b}$ & $6.366 \mathrm{~b}$ & $6.257 \mathrm{~b}$ & & \\
\hline & 520 & $7.132 \mathrm{a}$ & $7.293 \mathrm{a}$ & $7.190 \mathrm{a}$ & & \\
\hline \multirow{3}{*}{$\begin{array}{l}\text { Magnetic } \\
\text { water } \\
\times \text { Humic } \\
\text { acid }\end{array}$} & 0 & $5.712 \mathrm{~d}$ & $5.791 \mathrm{~d}$ & $5.740 \mathrm{~d}$ & \multicolumn{2}{|c|}{$5.746 \mathrm{c}$} \\
\hline & 12 & $6.383 \mathrm{c}$ & $6.505 \mathrm{c}$ & $6.345 \mathrm{c}$ & \multicolumn{2}{|c|}{$6.411 \mathrm{~b}$} \\
\hline & 24 & $7.190 \mathrm{ab}$ & $7.214 \mathrm{a}$ & $7.00 \mathrm{~b}$ & \multicolumn{2}{|c|}{$7.117 \mathrm{a}$} \\
\hline \multicolumn{2}{|c|}{ Humic acid effect } & $6.410 \mathrm{ab}$ & $6.503 \mathrm{a}$ & $6.340 \mathrm{~b}$ & & \\
\hline
\end{tabular}

*Means followed by the same letter for each factor and interaction do not differ significantly from each other's according to Duncan's Multiple range Test at 5\% level.

Photosynthesis Pigments, Oil Yield Contain and Chemical Compounds. Chlorophyll a content $\left(\mu \mathrm{g} \cdot \mathrm{mg}^{-1}\right)$

Table (7) indicated that significant value of chlorophyll a content in the plants was obtained when $\mathrm{P}_{2} \mathrm{O}_{5}$ fertilizer at $520 \mathrm{mg} \cdot \mathrm{pot}^{-1}$ was used $\left(20.21 \mu \mathrm{g} \cdot \mathrm{mg}^{-1}\right)$, 
while untreated plants showed the lowest value $\left(16.14 \mu \mathrm{g} \cdot \mathrm{mg}^{-1}\right)$. Irrigated the plants with magnetic water $24 \mathrm{~h}$ had significant effect on the chlorophyll a content (20.24 $\left.\mu \mathrm{g} . \mathrm{mg}^{-1}\right)$ as compared to other treatments (16.14 and 17.81 $\mu \mathrm{g} . \mathrm{mg}^{-1}$ ) respectively for 0 and $12 \mathrm{~h}$ magnetic water. Despite there was no significant difference between the both concentration of humic acid $(0.6$ and $\left.0.8 \mathrm{mg} . \mathrm{L}^{-1}\right)$, but were differs with $0 \mathrm{mg} . \mathrm{L}^{-1}$ and the values were $(17.84,18.11$ and $18.24 \mu \mathrm{g} . \mathrm{mg}^{-1}$ ) respectively. The interaction between $\mathrm{P}_{2} \mathrm{O}_{5}$ at $520 \mathrm{mg}$ pot $^{-1}$ and magnetic water with $24 \mathrm{~h}$ obtained significant effect on content of chlorophyll a (22. $\left.39 \mu \mathrm{g} . \mathrm{mg}^{-1}\right)$ as compared to untreated plants $\left(14.21 \mu \mathrm{g} . \mathrm{mg}^{-1}\right)$, while the interaction between $\mathrm{P}_{2} \mathrm{O}_{5}$ fertilizer at $520 \mathrm{mg}$ pot $^{-1}$ and humic acid at both 0.6 and $0.8 \mathrm{mg} . \mathrm{L}^{-1}$ the values were $\left(20.24\right.$ and $\left.20.45 \mu \mathrm{g} . \mathrm{mg}^{-1}\right)$ they were significantly differs with other treatments especially $\mathrm{P}_{2} \mathrm{O}_{5}$ fertilizer at 0 mg.pot ${ }^{-1}$ with all concentrations of humic acid $\left(15.98,16.15\right.$ and $16.27 \mu \mathrm{g} . \mathrm{mg}^{-}$ ${ }^{1}$ ). Applying humic acid at $0.8 \mathrm{mg} \cdot \mathrm{L}^{-1}$ interacted with magnetic water for $24 \mathrm{~h}$ showed significant effect $\left(20.72 \mu \mathrm{g} \cdot \mathrm{mg}^{-1}\right)$ compared to $0 \mathrm{~h}$ magnetic water with all concentrations of humic acid $\left(16.08,16.18\right.$ and $\left.16.15 \mu \mathrm{g} . \mathrm{mg}^{-1}\right)$.The triple interaction among $\mathrm{P}_{2} \mathrm{O}_{5}$ at 520 mg.pot ${ }^{-1}$, magnetic water for $24 \mathrm{~h}$ and humic acid at (0.6 and $\left.0.8 \mathrm{mg} . \mathrm{L}^{-1}\right)$ obtained significant values of chlorophyll a content (22.34 and $\left.22.94 \mu \mathrm{g} . \mathrm{mg}^{-1}\right)$ respectively compared to all treatments especially $0 \mathrm{P}_{2} \mathrm{O}_{5} \mathrm{mg}$ pot $^{-1}$, $0 \mathrm{~h}$ magnetic water and all concentrations of humic acid ( $14.22,14.23$ and $\left.14.19 \mu \mathrm{g} \cdot \mathrm{mg}^{-1}\right)$ respectively.

Chlorophyll b content ( $\left.\mu \mathrm{g} \cdot \mathrm{mg}^{-1}\right)$.

The results in Table (8) showed that the highest value of chlorophyll $b$ contents in the plants was conducted when $\mathrm{p}_{2} \mathrm{O}_{5}$ fertilizer at $520 \mathrm{mg}^{-p^{-1}}{ }^{-1}$ was used $\left(6.99 \mu \mathrm{g} . \mathrm{mg}^{-1}\right)$ while untreated plants gave the lowest value $\left(5.25 \mu \mathrm{g} \cdot \mathrm{mg}^{1}\right)$. Treating the plants with magnetic water for $24 \mathrm{~h}$ had significant effect on the chlorophyll $\mathrm{b}$ contents compared to the plants irrigated with tap water (6.91 and $5.18 \mu \mathrm{g} . \mathrm{mg}^{-1}$ ) respectively. All the concentrations of humic acid had no significant effect on chlorophyll $\mathrm{b}$ contents. The interaction treatment between $\mathrm{P}_{2} \mathrm{O}_{5}$ at $520 \mathrm{mg}$.pot ${ }^{-1}$ and with magnetic water for $24 \mathrm{~h}$ gave significant effect on the content of chlorophyll b content $\left(7.58 \mu \mathrm{g} . \mathrm{mg}^{-1}\right)$ as compared to untreated plants $\left(5.25 \mu \mathrm{g} \cdot \mathrm{mg}^{-1}\right)$. Applying $\mathrm{P}_{2} \mathrm{O}_{5}$ at $520 \mathrm{mg}^{-p^{-1}}{ }^{-1}$ with and humic acid at all concentrations had significant effect on chlorophyll $\mathrm{b}$ content the values were $\left(6.98,6.95\right.$ and $\left.7.06 \mu \mathrm{g} . \mathrm{mg}^{-1}\right)$ respectively as compared with all the treatments especially the lowest value obtained from. $\mathrm{P}_{2} \mathrm{O}_{5}$ at $520 \mathrm{mg}$.pot ${ }^{-1}$ interacted with all concentrations of humic acid the values were respectively $\left(5.11,5.25\right.$ and $\left.5.40 \mu \mathrm{g} . \mathrm{mg}^{-1}\right)$. The same direction was observed when the plants were treated with humic acid at $\left(0.0,0.6\right.$ and $\left.0.8 \mathrm{mg} . \mathrm{L}^{-1}\right)$ interacted with magnetic water for $24 \mathrm{~h}$ had significant effects $\left(6.80,6.99\right.$ and $6.95 \mu \mathrm{g} . \mathrm{mg}^{-}$ $\left.{ }^{1}\right)$ respectively as compared to untreated plants $\left(5.12,5.20\right.$ and $\left.5.22 \mu \mathrm{g} . \mathrm{mg}^{-1}\right)$ in chlorophyll b contents. The triple interaction of $\mathrm{P}_{2} \mathrm{O}_{5}$ at 520 mg.pot ${ }^{1}$, magnetic water for $24 \mathrm{~h}$ and humic acid at all concentrations showed significant effect 
of chlorophyll b content obtained (7.77,7.87 and $\left.7.92 \mu \mathrm{g} \cdot \mathrm{mg}^{1}\right)$ as compared to $\mathrm{P}_{2} \mathrm{O}_{5}$ at $0 \mathrm{mg}$.pot ${ }^{-1}$, magnetic water for $0 \mathrm{~h}$ with all concentrations of humic acid ( 4.22,4.39 and $4.53 \mu \mathrm{g} \cdot \mathrm{mg}^{-1}$ ) respectively.

Table (7): Effect of magnetic water, humic acid and phosphor fertilizer on the chlorophyll a of Nigella sativus plant $\left(\mu \mathrm{g} . \mathrm{mg}^{-1}\right)$.

\begin{tabular}{|c|c|c|c|c|c|c|}
\hline \multirow{2}{*}{$\begin{array}{c}\mathrm{P}_{2} \mathrm{O}_{5} \\
\left(\mathrm{mg} \cdot \text { pot }^{-1}\right)\end{array}$} & \multirow{2}{*}{$\begin{array}{c}\text { Magnetic } \\
\text { water } \\
\text { (hours) }\end{array}$} & \multicolumn{3}{|c|}{ Humic acid( mg.L $\left.L^{-1}\right)$} & \multirow{2}{*}{$\begin{array}{c}\mathrm{P}_{2} \mathrm{O}_{5} \\
\times \begin{array}{l}\text { Magnetic } \\
\text { water }\end{array} \\
\end{array}$} & \multirow{2}{*}{$\begin{array}{l}\mathrm{P}_{2} \mathrm{O}_{5} \\
\text { effect }\end{array}$} \\
\hline & & 0 & 0.6 & 0.8 & & \\
\hline \multirow[t]{3}{*}{0} & 0 & $14.22 \mathrm{i}$ & $14.23 \mathrm{i}$ & $14.19 \mathrm{i}$ & $14.21 \mathrm{f}$ & \multirow[t]{3}{*}{$16.14 \mathrm{c}$} \\
\hline & 12 & $\begin{array}{c}15.79 \\
\mathrm{~h}\end{array}$ & $\begin{array}{c}15.98 \\
\mathrm{~h}\end{array}$ & $\begin{array}{c}15.87 \\
\mathrm{~h}\end{array}$ & $15.88 \mathrm{e}$ & \\
\hline & 24 & $\begin{array}{l}17.94 \\
\text { fg }\end{array}$ & $\begin{array}{c}18.25 \\
\text { ef }\end{array}$ & $18.76 \mathrm{e}$ & $18.32 \mathrm{c}$ & \\
\hline \multirow[t]{3}{*}{260} & 0 & $\begin{array}{c}15.85 \\
\mathrm{~h}\end{array}$ & $\begin{array}{c}16.01 \\
\mathrm{~h}\end{array}$ & $\begin{array}{c}15.90 \\
\mathrm{~h}\end{array}$ & $15.92 \mathrm{e}$ & \multirow[t]{3}{*}{$17.84 \mathrm{~b}$} \\
\hline & 12 & $\begin{array}{c}17.42 \\
\mathrm{~g}\end{array}$ & $\begin{array}{c}17.76 \\
\text { fg }\end{array}$ & $\begin{array}{c}17.58 \\
\text { fg }\end{array}$ & $17.59 \mathrm{~d}$ & \\
\hline & 24 & $\begin{array}{c}19.57 \\
\text { d }\end{array}$ & $\begin{array}{c}20.03 \\
\mathrm{~cd}\end{array}$ & $20.47 \mathrm{c}$ & $20.02 \mathrm{~b}$ & \\
\hline \multirow[t]{3}{*}{520} & 0 & $\begin{array}{l}18.17 \\
\text { e-g }\end{array}$ & $\begin{array}{c}18.32 \\
\text { ef }\end{array}$ & $\begin{array}{c}18.37 \\
\text { ef }\end{array}$ & $18.29 \mathrm{c}$ & \multirow[t]{3}{*}{$20.21 \mathrm{a}$} \\
\hline & 12 & $\begin{array}{c}19.74 \\
\mathrm{~cd}\end{array}$ & $\begin{array}{c}20.07 \\
\text { cd }\end{array}$ & $\begin{array}{c}20.05 \\
\mathrm{~cd}\end{array}$ & $19.95 \mathrm{~b}$ & \\
\hline & 24 & $\begin{array}{c}21.89 \\
\mathrm{~b}\end{array}$ & $\begin{array}{c}22.34 \\
a b\end{array}$ & $22.94 \mathrm{a}$ & $22.39 \mathrm{a}$ & \\
\hline \multirow{3}{*}{$\begin{aligned} & \mathrm{P}_{2} \mathrm{O}_{5} \\
\times & \mathrm{Humic} \\
& \text { acid }\end{aligned}$} & 0 & $15.98 \mathrm{e}$ & $16.15 \mathrm{e}$ & $16.27 \mathrm{e}$ & \multirow{3}{*}{\multicolumn{2}{|c|}{$\begin{array}{l}\text { Magnetic water } \\
\text { Effect }\end{array}$}} \\
\hline & 260 & $\begin{array}{c}17.61 \\
\mathrm{~d}\end{array}$ & $\begin{array}{l}17.93 \\
\mathrm{~cd}\end{array}$ & $17.99 \mathrm{c}$ & & \\
\hline & 520 & $\begin{array}{c}19.93 \\
\text { b }\end{array}$ & $\begin{array}{c}20.24 \\
\text { ab }\end{array}$ & $20.45 \mathrm{a}$ & & \\
\hline \multirow{3}{*}{$\begin{array}{l}\text { Magnetic } \\
\text { water } \\
\times \text { Humic } \\
\text { acid }\end{array}$} & 0 & $16.08 \mathrm{e}$ & $16.18 \mathrm{e}$ & $16.15 \mathrm{e}$ & \multicolumn{2}{|c|}{$16.14 \mathrm{c}$} \\
\hline & 12 & $\begin{array}{c}17.65 \\
\mathrm{~d}\end{array}$ & $17.94 \mathrm{c}$ & $\begin{array}{l}17.83 \\
\mathrm{~cd}\end{array}$ & \multicolumn{2}{|c|}{$17.81 \mathrm{~b}$} \\
\hline & 24 & $\begin{array}{c}19.80 \\
\mathrm{~b}\end{array}$ & $\begin{array}{c}20.20 \\
\mathrm{~b}\end{array}$ & $20.72 \mathrm{a}$ & \multicolumn{2}{|c|}{$20.24 \mathrm{a}$} \\
\hline \multicolumn{2}{|c|}{ Humic acid effect } & $\begin{array}{c}17.84 \\
\mathrm{~b}\end{array}$ & $18.11 \mathrm{a}$ & $18.24 \mathrm{a}$ & & \\
\hline
\end{tabular}

*Means followed by the same letter for each factor and interaction do not differ significantly from each other's according to Duncan's Multiple range Test at 5\% level. 
Table (8): Effect of magnetic water, humic acid and phosphor fertilizer on the chlorophyll b of Nigella sativus plant ( $\left.\mu \mathrm{g} \cdot \mathrm{mg}^{-1}\right)$.

\begin{tabular}{|c|c|c|c|c|c|c|}
\hline \multirow{2}{*}{$\begin{array}{c}\mathrm{P}_{2} \mathrm{O}_{5} \\
\left(\mathrm{mg} \cdot \text { pot }^{-}\right. \\
1)\end{array}$} & \multirow{2}{*}{$\begin{array}{l}\text { Magnetic } \\
\text { water } \\
\text { (hours) }\end{array}$} & \multicolumn{3}{|c|}{ Humic acid( mg. $\left.\mathrm{L}^{-1}\right)$} & \multirow{2}{*}{$\begin{array}{l}\mathrm{P}_{2} \mathrm{O}_{5} \\
\times \quad \text { Magnetic } \\
\text { water } \\
\end{array}$} & \multirow{2}{*}{$\begin{array}{l}\mathrm{P}_{2} \mathrm{O}_{5} \\
\text { effect }\end{array}$} \\
\hline & & 0 & 0.6 & 0.8 & & \\
\hline \multirow[t]{3}{*}{0} & 0 & $4.22 \mathrm{~g}$ & $4.39 \mathrm{~g}$ & $4.53 \mathrm{~g}$ & $4.38 \mathrm{~g}$ & \multirow[t]{3}{*}{$5.25 \mathrm{c}$} \\
\hline & 12 & $5.21 \mathrm{ef}$ & $5.19 \mathrm{ef}$ & $5.39 \mathrm{e}$ & $5.27 \mathrm{e}$ & \\
\hline & 24 & $5.89 \mathrm{~d}$ & $6.18 \mathrm{~d}$ & $6.26 \mathrm{~d}$ & $6.11 \mathrm{~d}$ & \\
\hline \multirow[t]{3}{*}{260} & 0 & 5.0 ef6 & $5.12 \mathrm{ef}$ & $4.92 \mathrm{f}$ & $5.03 \mathrm{f}$ & \multirow[t]{3}{*}{$5.91 \mathrm{~b}$} \\
\hline & 12 & $6.05 \mathrm{~d}$ & $5.92 \mathrm{~d}$ & $5.79 \mathrm{~d}$ & $5.92 \mathrm{~d}$ & \\
\hline & 24 & $6.73 \mathrm{bc}$ & $6.91 \mathrm{bc}$ & $6.65 \mathrm{c}$ & $6.76 \mathrm{c}$ & \\
\hline \multirow[t]{3}{*}{520} & 0 & $6.09 \mathrm{~d}$ & $6.08 \mathrm{~d}$ & $6.19 \mathrm{~d}$ & $6.12 \mathrm{~d}$ & \multirow[t]{3}{*}{$6.99 \mathrm{a}$} \\
\hline & 260 & $7.09 \mathrm{~b}$ & $6.89 \mathrm{bc}$ & $7.05 \mathrm{~b}$ & $7.01 \mathrm{~b}$ & \\
\hline & 520 & $7.77 \mathrm{a}$ & $7.87 \mathrm{a}$ & $7.92 \mathrm{a}$ & $7.85 \mathrm{a}$ & \\
\hline \multirow{3}{*}{$\begin{array}{l}\mathrm{P}_{2} \mathrm{O}_{5} \\
\times \underset{\text { acid }}{\mathrm{Humic}}\end{array}$} & 0 & $5.11 \mathrm{c}$ & $5.25 \mathrm{c}$ & $5.40 \mathrm{c}$ & \multirow{3}{*}{\multicolumn{2}{|c|}{$\begin{array}{c}\text { Magnetic water } \\
\text { effect }\end{array}$}} \\
\hline & 260 & $5.95 \mathrm{~b}$ & $5.98 \mathrm{~b}$ & $5.79 \mathrm{~b}$ & & \\
\hline & 520 & $6.98 \mathrm{a}$ & $6.95 a$ & $7.06 \mathrm{a}$ & & \\
\hline \multirow{3}{*}{$\begin{array}{l}\text { Magnetic } \\
\text { water } \\
\times \text { Humic } \\
\text { acid } \\
\end{array}$} & 0 & $5.12 \mathrm{c}$ & $5.20 \mathrm{c}$ & $5.22 \mathrm{c}$ & \multicolumn{2}{|c|}{$5.18 \mathrm{c}$} \\
\hline & 12 & $6.12 \mathrm{~b}$ & $6.00 \mathrm{~b}$ & $6.08 \mathrm{~b}$ & \multicolumn{2}{|c|}{$6.07 \mathrm{~b}$} \\
\hline & 24 & $6.80 \mathrm{a}$ & $6.99 \mathrm{a}$ & $6.95 \mathrm{a}$ & \multicolumn{2}{|c|}{$6.91 \mathrm{a}$} \\
\hline \multicolumn{2}{|c|}{ Humic acid effect } & $6.01 \mathrm{a}$ & $6.06 \mathrm{a}$ & $6.08 \mathrm{a}$ & & \\
\hline
\end{tabular}

*Means followed by the same letter for each factor and interaction do not differ significantly from each other's according to Duncan's Multiple range Test at 5\% level.

Total chlorophyll content $\left(\mu \mathrm{g} \cdot \mathrm{mg}^{-1}\right)$

The results in Table (9) pointed out that $\mathrm{P}_{2} \mathrm{O}_{5}$ feltrizer at $520 \mathrm{mg}_{\text {. pot }}{ }^{-1}$ gave the significant value of total chlorophyll $\left(28.04 \mu \mathrm{g} . \mathrm{mg}^{-1}\right)$ as compared to (21.79 and $24.61 \mu \mathrm{g} \cdot \mathrm{mg}^{-1}$ ) were obtained with 0 and $260 \mathrm{mg} \cdot \mathrm{pot}^{-1} \mathrm{P}_{2} \mathrm{O}_{5}$. Irrigating the plants with magnetic water for $24 \mathrm{~h}$ was significantly differed with the plans that irrigated with tap water and magnetic water for $12 \mathrm{~h}$ they were respectively $(28.04,21.70$ and $\left.24.38 \mu \mathrm{g} . \mathrm{mg}^{-1}\right)$. Applying humic acid at $\left(0.8 \mathrm{mg} . \mathrm{L}^{-1}\right)$ had significant effect on the content of total chlorophyll in plant $\left(24.98 \mu \mathrm{g} . \mathrm{mg}^{-1}\right)$ as compared to $(24.74$ and $\left.24.73 \mu \mathrm{g} . \mathrm{mg}^{-1}\right)$ respectively for $\left(0\right.$ and $0.6 \mathrm{mg} \cdot \mathrm{L}^{-1)}$. The interaction between $\mathrm{P}_{2} \mathrm{O}_{5}$ feltrizer at $520 \mathrm{mg}$.pot ${ }^{-1}$ and magnetic water with $24 \mathrm{~h}$ showed significant effect on content of total chlorophyll content $\left(31.59 \mu \mathrm{g} . \mathrm{mg}^{-1}\right)$ as compared to other treatments especially untreated plants $\left(18.68 \mu \mathrm{g} \cdot \mathrm{mg}^{-1}\right)$. Significant difference obtained when used with humic acid at all concentrations the values were (27.88 ,28.10 and $28.15 \mu \mathrm{g} \cdot \mathrm{mg}^{-1}$ ) when compared to other treatments especially when $\mathrm{P}_{2} \mathrm{O}_{5}$ feltrizer at $0 \mathrm{mg} \cdot$ pot $^{-1}$ used with humic acid at all concentrations $(21.94,21.55$ and $21.88 \mu \mathrm{g} . \mathrm{mg}^{-1}$ ) respectively. When the plants were treated with humic acid at all concentrations interacted with magnetic water for $24 \mathrm{~h}$ showed significant effect on total chlorophyll contents. $\left(28.24,28.32\right.$ and $\left.28.54 \mu \mathrm{g} . \mathrm{mg}^{-1}\right)$ respectively and the lowest values were obtained from untreated plants $(21.87,21.44$ and 21.78 $\mu$ g. $\left.\mathrm{mg}^{-1}\right)$. The triple interaction $\mathrm{P}_{2} \mathrm{O}_{5}$ feltrizer at $520 \mathrm{mg}$.pot ${ }^{-1}$, magnetic water with 
$24 \mathrm{~h}$ and humic acid at all concentrations showed significant values of total chlorophyll content $\left(31.38,31.69\right.$ and $\left.31.71 \mu \mathrm{g} . \mathrm{mg}^{-1}\right)$ as compared to other treatments but the lowest values were. (19.07,18.27 and $\left.18.69 \mu \mathrm{g} . \mathrm{mg}^{-1}\right)$ respectively for $\mathrm{P}_{2} \mathrm{O}_{5}$ feltrizer at $0 \mathrm{mg}$.pot ${ }^{-1}$,tap water and humic acid with all concentrationa.

Table (9): Effect of magnetic water, humic acid and phosphor fertilizer on the total chlorophyll of Nigella sativus plant.

\begin{tabular}{|c|c|c|c|c|c|c|}
\hline \multirow{2}{*}{$\begin{array}{c}\mathrm{P}_{2} \mathrm{O}_{5} \\
\left(\mathrm{mg} \cdot \text { pot }^{-1}\right)\end{array}$} & \multirow{2}{*}{$\begin{array}{l}\text { Magnetic } \\
\text { water } \\
\text { (hours) }\end{array}$} & \multicolumn{3}{|c|}{ Humic acid( mg. $\left.L^{-1}\right)$} & \multirow{2}{*}{$\begin{array}{c}\mathrm{P}_{2} \mathrm{O}_{5} \\
\times \\
\text { Magnetic } \\
\text { water }\end{array}$} & \multirow{2}{*}{$\begin{array}{l}\mathrm{P}_{2} \mathrm{O}_{5} \\
\text { effect }\end{array}$} \\
\hline & & 0 & 0.6 & 0.8 & & \\
\hline \multirow[t]{3}{*}{0} & 0 & $19.07 \mathrm{~h}$ & $18.27 \mathrm{i}$ & $18.69 \mathrm{hi}$ & $18.68 \mathrm{~g}$ & \multirow[t]{3}{*}{$21.79 \mathrm{c}$} \\
\hline & 12 & $21.31 \mathrm{~g}$ & $21.25 \mathrm{~g}$ & $21.52 \mathrm{~g}$ & $21.36 \mathrm{~g}$ & \\
\hline & 24 & $25.44 \mathrm{~d}$ & $25.15 \mathrm{~d}$ & $25.44 \mathrm{~d}$ & $25.34 \mathrm{~d}$ & \\
\hline \multirow[t]{3}{*}{260} & 0 & $21.54 \mathrm{~g}$ & $21.24 \mathrm{~g}$ & $21.70 \mathrm{~g}$ & $21.49 \mathrm{~g}$ & \multirow[t]{3}{*}{$24.61 \mathrm{~b}$} \\
\hline & 12 & $23.78 \mathrm{f}$ & $24.22 \mathrm{ef}$ & $24.53 \mathrm{ef}$ & $24.17 \mathrm{f}$ & \\
\hline & 24 & $27.91 b c$ & $28.12 b$ & $28.45 \mathrm{~b}$ & $28.16 \mathrm{~b}$ & \\
\hline \multirow[t]{3}{*}{520} & 0 & $25.01 \mathrm{~d}$ & $24.82 \mathrm{de}$ & $24.96 \mathrm{~d}$ & $24.93 \mathrm{e}$ & \multirow[t]{3}{*}{$28.04 \mathrm{a}$} \\
\hline & 12 & $27.25 \mathrm{c}$ & $27.79 \mathrm{bc}$ & $27.79 \mathrm{bc}$ & $27.61 \mathrm{c}$ & \\
\hline & 24 & $31.38 \mathrm{a}$ & $31.69 \mathrm{a}$ & $31.71 \mathrm{a}$ & $31.59 \mathrm{a}$ & \\
\hline \multirow{3}{*}{$\begin{array}{c}\mathrm{P}_{2} \mathrm{O}_{5} \\
\times \text { Humic } \\
\text { acid }\end{array}$} & 0 & $21.94 \mathrm{~d}$ & $21.55 \mathrm{~d}$ & $21.88 \mathrm{~d}$ & \multirow{3}{*}{\multicolumn{2}{|c|}{$\begin{array}{l}\text { Magnetic water } \\
\text { effect }\end{array}$}} \\
\hline & 260 & $24.41 \mathrm{c}$ & $24.53 \mathrm{c}$ & $24.89 \mathrm{~b}$ & & \\
\hline & 520 & $27.88 \mathrm{a}$ & $28.10 \mathrm{a}$ & $28.15 \mathrm{a}$ & & \\
\hline \multirow{3}{*}{$\begin{array}{l}\text { Magnetic } \\
\text { water } \\
\times \text { Humic } \\
\text { acid }\end{array}$} & 0 & $21.87 \mathrm{~d}$ & $21.44 \mathrm{e}$ & $21.78 \mathrm{de}$ & \multicolumn{2}{|c|}{$21.70 \mathrm{c}$} \\
\hline & 12 & $24.11 \mathrm{c}$ & $24.42 \mathrm{c}$ & $24.61 \mathrm{~b}$ & \multicolumn{2}{|c|}{$24.38 \mathrm{~b}$} \\
\hline & 24 & $28.24 \mathrm{a}$ & $28.32 \mathrm{a}$ & $28.54 \mathrm{a}$ & \multicolumn{2}{|c|}{$28.36 \mathrm{a}$} \\
\hline \multicolumn{2}{|c|}{ Humic acid effect } & $24.74 \mathrm{~b}$ & $24.73 \mathrm{~b}$ & $24.98 \mathrm{a}$ & & \\
\hline
\end{tabular}

*Means followed by the same letter for each factor and interaction do not differ significantly from each other's according to Duncan's Multiple range Test at 5\% level.

volatile oil percentage $(\%)$.

The results in Table (10) indicated that $\mathrm{p}_{2} \mathrm{O}_{5}$ fertilizer at $\mathrm{P}_{2} \mathrm{O}_{5}$ feltrizer at $520 \mathrm{mg}$.pot ${ }^{-1}$ significantly increased the volatile oil content $(0.823 \%)$ as compared to 0 and 260 mg.pot ${ }^{-1}(0.795$ and $0.819 \%)$, also the same Table mentioned that the effect of magnetic water for $24 \mathrm{~h}$ was significantly increased the content of volatile oil to $(0.833 \%)$ in compression with the plants irrigated with tap water and magnetic water $(0.785$ and $0.818 \%)$. Applying the humic acid had significant effect on the volatile oil content especially at $0.8 \mathrm{mg}$.L- ${ }^{-1}$ it was $(0.815 \%)$ while 0 and 0.6 gave lowest values ( 0.811 and 0.811 ) respectively. The interaction between $\mathrm{P}_{2} \mathrm{O}_{5}$ feltrizer at $520 \mathrm{mg} \cdot$ pot $^{-1}$ and magnetic water for $24 \mathrm{~h}$ showed a significant effect on content of volatile oil ( $0.844 \%)$ while the lowest value obtained from 1 untreated plants $(0$. $767 \%)$. Significant difference noticed when $\mathrm{P}_{2} \mathrm{O}_{5}$ feltrizer at 520 mg.pot ${ }^{-1}$ used with and humic acid at $0.8 \mathrm{mg} \cdot \mathrm{L}^{-1}$ on the content of volatile oil $(0.828 \%)$ as compared to lowest value of volatile oil content $(0.792,0.794$ and $0.795 \%)$. Respectively from 0 
mg.pot ${ }^{-1} \mathrm{P}_{2} \mathrm{O}_{5}$ feltrizer with all the concentrations of humic acid Despite when the plants were treated with humic acid at all concentrations interacted with magnetic water for $24 \mathrm{~h}$ did not show significant different $\left(\begin{array}{lll}0.833 & 0.832 \text { and }\end{array}\right.$ $0.835 \%$ ) respectively but they were significantly differ with other treatments especially the plants irrigated with tap water interacted with all concentrations of humic acid $(0.783,0.782$ and $0.789 \%)$ respectively Treating the plants with $\mathrm{P}_{2} \mathrm{O}_{5}$ feltrizer at $520 \mathrm{mg}$.pot ${ }^{-1}$, magnetic water with $24 \mathrm{~h}$ and humic acid at all concentrations gave significant values of volatile oil content especially at 0.8 mg. $\mathrm{L}^{1}$, the values were $(0.842,0.842$ and $0.848 \%)$ when compared to all treatments. $(0.767,0.766$ and $0.769 \%)$ respectively for $\mathrm{P}_{2} \mathrm{O}_{5}$ feltrizer at $0 \mathrm{mg}$ pot $^{-1}$, magnetic water with $0 \mathrm{~h}$ and humic acid at all concentrations.

Table (11) conducted that treating the plants Table (12) showed that fertilizer at $\mathrm{P}_{2} \mathrm{O}_{5}$ feltrizer at $520 \mathrm{mg} \cdot$ pot $^{-1}$ significantly increased the fixed oil content $(38.45 \%)$ as compared to 0 and $260 \mathrm{mg}^{-p^{-1} \mathrm{t}^{-1}}$ (35.74 and $36.15 \%$ ), Irrigating the plants with magnetic water for $24 \mathrm{~h}$ to was significantly differed with the plans that irrigated with tap water and magnetic water for $12 \mathrm{~h}$ the values were respectively (37.06 \%, 35. 04 and $37.42 \%)$.Humic acid had no significant effect on the content of fixed oil in plant at all concentrations. The interaction between $\mathrm{P}_{2} \mathrm{O}_{5}$ feltrizer at $520 \mathrm{mg}$.pot ${ }^{-1}$ and magnetic water for $24 \mathrm{~h}$ showed significant effect on content of fixed oil (39. 58\%) as compared to other treatments especially untreated plants $(33.99 \%)$. There was significant difference noticed when $\mathrm{P}_{2} \mathrm{O}_{5}$ feltrizer at $520 \mathrm{mg}$ pot $^{-1}$ used with humic acid at all concentrations and the values were $(37.87,38.01$ and $37.85 \%)$ respectively when compared with other treatments especially when $\mathrm{p}_{2} \mathrm{O}_{5}$ fertilizer at 0 mg.pot ${ }^{-1}$ interacted with humic acid at all concentrations $(35.12,35.58$ and $35.52 \%$ ). respectively When the plants were treated with humic acid at all concentrations interacted with magnetic water for $24 \mathrm{~h}$ showed significant different with other treatments $(37.29,36.85$ and $37.05 \%)$ respectively but the lowest values were untreated plants $(35.31,34.95$ and $34.84 \%)$ in fixed oil contents. The triple interaction of $\mathrm{P}_{2} \mathrm{O}_{5}$ feltrizer at $520 \mathrm{mg} \cdot$ pot $^{-1}$, magnetic water for $24 \mathrm{~h}$ and humic acid at all concentrations and $\mathrm{P}_{2} \mathrm{O}_{5}$ feltrizer at $520 \mathrm{mg} \cdot$ pot $^{-1}$, magnetic water for $12 \mathrm{~h}$ and humic acid at all concentrations showed the significant effect on fixed oil content the values were (39.56, 39.57 and 39.6 $\%)$ and $(38.90,39.26$ and $39.15 \%)$ as compared to other treatments especially lowest values obtained from interacted $\mathrm{P}_{2} \mathrm{O}_{5}$ feltrizer at o mg.pot ${ }^{-1}$, magnetic water for $\mathrm{o} h$ with all concentrations of humic acid.( 34,52,33.81 and $33.64 \%)$ respectively. 
Table (10): Effect of magnetic water, humic acid and phosphor fertilizer on the volatile oil (\%) of Nigella sativus plant.

\begin{tabular}{|c|c|c|c|c|c|c|}
\hline \multirow{2}{*}{$\begin{array}{c}\mathrm{P}_{2} \mathrm{O}_{5} \\
\left(\mathrm{mg} \cdot \text { pot }^{-1}\right)\end{array}$} & \multirow{2}{*}{$\begin{array}{l}\text { Magnetic } \\
\text { water } \\
\text { (hours) }\end{array}$} & \multicolumn{3}{|c|}{ Humic acid( $\left.\mathrm{mg} \cdot \mathrm{L}^{-1}\right)$} & \multirow{2}{*}{$\begin{array}{c}\mathrm{P}_{2} \mathrm{O}_{5} \\
\times \begin{array}{l}\text { Magnetic } \\
\text { water }\end{array}\end{array}$} & \multirow{2}{*}{$\begin{array}{l}\mathrm{P}_{2} \mathrm{O}_{5} \\
\text { effect }\end{array}$} \\
\hline & & 0 & 0.6 & 0.8 & & \\
\hline \multirow[t]{3}{*}{0} & 0 & $0.767 \mathrm{k}$ & $0.766 \mathrm{k}$ & $0.769 \mathrm{k}$ & $0.767 \mathrm{f}$ & \multirow[t]{3}{*}{$0.795 \mathrm{c}$} \\
\hline & 12 & $0.800 \mathrm{hi}$ & $0.801 \mathrm{~h}$ & $0.802 \mathrm{~h}$ & $0.801 \mathrm{~d}$ & \\
\hline & 24 & $0.817 \mathrm{gf}$ & $0.816 \mathrm{gf}$ & $0.815 \mathrm{~g}$ & $0.816 \mathrm{c}$ & \\
\hline \multirow[t]{3}{*}{260} & 0 & $0.791 \mathrm{j}$ & $0.789 \mathrm{j}$ & $0.795 \mathrm{hj}$ & $0.792 \mathrm{e}$ & \multirow[t]{3}{*}{$0.819 \mathrm{~b}$} \\
\hline & 12 & 0.824 ef & $0.824 \mathrm{ef}$ & $0.828 \mathrm{~cd}$ & $0.825 \mathrm{~b}$ & \\
\hline & 24 & $0.841 \mathrm{ab}$ & $0.839 \mathrm{~b}$ & $0.841 \mathrm{ab}$ & $0.840 \mathrm{a}$ & \\
\hline \multirow[t]{3}{*}{520} & 0 & $0.792 \mathrm{j}$ & $0.792 \mathrm{j}$ & $0.802 \mathrm{~h}$ & $0.795 \mathrm{e}$ & \multirow[t]{3}{*}{$0.823 \mathrm{a}$} \\
\hline & 12 & $0.825 \mathrm{de}$ & $0.827 \mathrm{~cd}$ & $0.835 \mathrm{bc}$ & $0.829 \mathrm{~b}$ & \\
\hline & 24 & $0.842 \mathrm{ab}$ & $0.842 \mathrm{ab}$ & $0.848 \mathrm{a}$ & $0.844 \mathrm{a}$ & \\
\hline \multirow{3}{*}{$\begin{aligned} & \mathrm{P}_{2} \mathrm{O}_{5} \\
& \times \mathrm{Humic} \\
& \text { acid }\end{aligned}$} & 0 & $0.795 \mathrm{c}$ & $0.794 \mathrm{c}$ & $0.795 \mathrm{c}$ & \multirow{3}{*}{\multicolumn{2}{|c|}{$\begin{array}{l}\text { Magnetic water } \\
\text { effect }\end{array}$}} \\
\hline & 260 & $0.819 \mathrm{~b}$ & $0.817 \mathrm{~b}$ & $0.821 \mathrm{~b}$ & & \\
\hline & 520 & $0.820 \mathrm{~b}$ & $0.820 \mathrm{~b}$ & $0.828 \mathrm{a}$ & & \\
\hline \multirow{3}{*}{$\begin{array}{l}\text { Magnetic } \\
\text { water } \\
\times \text { Humic } \\
\text { acid }\end{array}$} & 0 & $0.783 c$ & $0.782 \mathrm{c}$ & $0.789 \mathrm{c}$ & \multicolumn{2}{|c|}{$0.785 \mathrm{c}$} \\
\hline & 12 & $0.816 \mathrm{~b}$ & $0.817 \mathrm{~b}$ & $0.822 \mathrm{~b}$ & \multicolumn{2}{|c|}{$0.818 \mathrm{~b}$} \\
\hline & 24 & $0.833 \mathrm{a}$ & $0.832 \mathrm{a}$ & $0.835 \mathrm{a}$ & \multicolumn{2}{|c|}{$0.833 \mathrm{a}$} \\
\hline \multicolumn{2}{|c|}{ Humic acid effect } & $0.811 \mathrm{~b}$ & $0.811 \mathrm{~b}$ & $0.815 \mathrm{a}$ & & \\
\hline
\end{tabular}

*Means followed by the same letter for each factor and interaction do not differ significantly from each other's according to Duncan's Multiple range Test at 5\% level.

Fixed oil percentage (\%)

Table (11): Effect of magnetic water, humic acid and phosphor fertilizer on the fixed oil (\%) of Nigella sativus plant .

\begin{tabular}{|c|c|c|c|c|c|c|}
\hline \multirow{2}{*}{$\begin{array}{c}\mathrm{P}_{2} \mathrm{O}_{5} \\
\left(\mathrm{mg} \cdot \mathrm{pot}^{-1}\right)\end{array}$} & \multirow{2}{*}{$\begin{array}{c}\text { Magnetic } \\
\text { water } \\
\text { (hours) }\end{array}$} & \multicolumn{3}{|c|}{ Humic acid( mg.L $\left.{ }^{-1}\right)$} & \multirow{2}{*}{$\begin{array}{c}\mathrm{P}_{2} \mathrm{O}_{5} \\
\times \quad \text { Magnetic } \\
\text { water }\end{array}$} & \multirow{2}{*}{$\begin{array}{l}\mathrm{P}_{2} \mathrm{O}_{5} \\
\text { effect }\end{array}$} \\
\hline & & 0 & 0.6 & 0.8 & & \\
\hline \multirow[t]{3}{*}{0} & 0 & $34.52 \mathrm{e}$ & $33.81 \mathrm{e}$ & $33.64 \mathrm{e}$ & $33.99 \mathrm{~d}$ & \multirow[t]{3}{*}{$35.74 \mathrm{c}$} \\
\hline & 12 & $36.58 \mathrm{c}-\mathrm{d}$ & $36.31 \mathrm{~d}$ & $36.24 d$ & $36.37 \mathrm{c}$ & \\
\hline & 24 & $37.25 \mathrm{c}-\mathrm{d}$ & $36.62 \mathrm{c}-\mathrm{d}$ & $36.70 \mathrm{c}-\mathrm{d}$ & $36.86 \mathrm{bc}$ & \\
\hline \multirow[t]{3}{*}{260} & 0 & $34.59 \mathrm{e}$ & $34.28 \mathrm{e}$ & $34.33 \mathrm{e}$ & $34.40 \mathrm{~d}$ & \multirow[t]{3}{*}{$36.15 \mathrm{~b}$} \\
\hline & 12 & $36.65 \mathrm{c}-\mathrm{d}$ & $36.78 \mathrm{c}-\mathrm{d}$ & $36.93 \mathrm{c}-\mathrm{d}$ & $36.78 \mathrm{bc}$ & \\
\hline & 24 & $37.33 \mathrm{bc}$ & $37.09 \mathrm{c}-\mathrm{d}$ & $37.39 \mathrm{~b}$ & $37.27 \mathrm{~b}$ & \\
\hline \multirow[t]{3}{*}{520} & 0 & $36.84 \mathrm{c}-\mathrm{d}$ & $36.76 \mathrm{c}-\mathrm{d}$ & $36.55 \mathrm{c}-\mathrm{d}$ & $36.72 \mathrm{c}$ & \multirow[t]{3}{*}{$38.46 \mathrm{a}$} \\
\hline & 12 & $38.90 \mathrm{a}$ & $39.26 \mathrm{a}$ & $39.15 \mathrm{a}$ & $39.10 \mathrm{ab}$ & \\
\hline & 24 & $39.56 \mathrm{a}$ & $39.57 \mathrm{a}$ & $39.61 \mathrm{a}$ & $39.58 \mathrm{a}$ & \\
\hline \multirow{3}{*}{$\begin{aligned} & \mathrm{P}_{2} \mathrm{O}_{5} \\
\times & \text { Humic } \\
& \text { acid }\end{aligned}$} & 0 & $36.12 \mathrm{~d}$ & $35.58 \mathrm{dc}$ & $35.52 \mathrm{~d}$ & \multirow{3}{*}{\multicolumn{2}{|c|}{$\begin{array}{c}\text { Magnetic water } \\
\text { Effect }\end{array}$}} \\
\hline & 260 & $36.19 \mathrm{~b}$ & $36.05 \mathrm{bc}$ & $36.21 \mathrm{~b}$ & & \\
\hline & 520 & $37.87 \mathrm{ab}$ & $38.01 \mathrm{a}$ & $37.85 \mathrm{ab}$ & & \\
\hline Magnetic & 0 & $35.31 \mathrm{c}$ & $34.95 \mathrm{c}$ & $34.84 \mathrm{c}$ & & \\
\hline
\end{tabular}




\begin{tabular}{|c|c|c|c|c|c|}
\hline \multirow{2}{*}{$\begin{array}{c}\text { water } \\
\times \text { Humic } \\
\text { acid } \\
\end{array}$} & 12 & $37.38 \mathrm{~b}$ & $37.45 \mathrm{~b}$ & $37.44 \mathrm{~b}$ & $37.42 \mathrm{~b}$ \\
\hline & 24 & $37.29 \mathrm{a}$ & $36.85 \mathrm{ab}$ & $37.05 \mathrm{a}$ & $37.06 \mathrm{a}$ \\
\hline \multicolumn{2}{|c|}{ Humic acid effect } & $36.58 \mathrm{a}$ & $36.36 \mathrm{a}$ & $36.37 \mathrm{a}$ & \\
\hline
\end{tabular}

*Means followed by the same letter for each factor and interaction do not differ significantly from each other's according to Duncan's Multiple range Test at 5\% level.

Total carbohydrates percentage

Table (12) showed that fertilizer at $\mathrm{P}_{2} \mathrm{O}_{5}$ feltrizer at $520 \mathrm{mg} \cdot \mathrm{pot}^{-1}$ significantly increased the total carbohydrates content $(29.73 \%)$ as compared to 0 and 260 mg.pot ${ }^{-1}$ (28.82 and $29.53 \%$ ), The data in the same Table showed that the effect of magnetic water for $24 \mathrm{~h}$ was significantly increased the content of total carbohydrates to (30.71) in compression with the plants irrigated with tap water and magnetic water for $14 \mathrm{~h}$ it was (27.85 and 29.52\%). Applying humic acid had no significant effect on the total carbohydrates content at all concentrations. The interaction between $\mathrm{P}_{2} \mathrm{O}_{5}$ feltrizer at $520 \mathrm{mg} \cdot$ pot $^{-1}$ and magnetic water with $24 \mathrm{~h}$ showed significant effect on content of total carbohydrates $(31.08 \%)$ as compared to other treatments, the lowest value obtained from untreated plants $(27.31 \%)$. $\mathrm{P}_{2} \mathrm{O}_{5}$ feltrizer at 260 and $520 \mathrm{mg} \cdot$ pot $^{-1}$ interacted with humic acid at all concentrations of humic acid the values were (29.48,29.55 and $29.56 \%)$; $(29.71,29.73$ and $29.75 \%)$ respectively for both treatments as comparison with loweast values obtained from using $\mathrm{P}_{2} \mathrm{O}_{5}$ feltrizer at 0 interacted with all humic acid concentrations $(28.98,29.04$ and $28.43 \%)$ respectively. Applying humic acid at $\left(0.0,0.6\right.$ and $\left.0.8 \mathrm{mg} . \mathrm{L}^{-1}\right)$ interacted with magnetic water for $24 \mathrm{~h}$ showed significant different $(30.44,30.85$ and $30.84 \%$ ) respectively with other treatments especially the plants irrigated with tap water interacted with $0 \mathrm{mg} . \mathrm{L}^{-1}(27.95,28.01$ and $27.57 \%$ ) respectively in total carbohydrates contents. The triple interaction using $\mathrm{P}_{2} \mathrm{O}_{5}$ feltrizer at $520 \mathrm{mg}$ pot $^{-1}$, magnetic water for $24 \mathrm{~h}$ and humic acid at $(0.0$, 0.6 and $0.8 \mathrm{mg} . \mathrm{L}^{-1}$ ) gave significant values of total carbohydrates content when compared to other treatments $(30.76,31.14$ and $31.34 \%)$ respectively while lowest values founded when plants treated with $0 \mathrm{mg}$. pot ${ }^{-1} \mathrm{P}_{2} \mathrm{O}_{5}$ feltrizer with tap water and all concentrations of humic acid $(27.54,27.62$ and $26.76 \%)$ respectively.

This significant increase in the characteristics of research is consistent with several researchers. (Singh et al., 1999) confirmed this finding. Garg and Malhotra (2008) mentioned that he results that height of plant, number of branches, number of leaves per plant stem diameter and seed yields increased with increasing of $\mathrm{P}_{2} \mathrm{O}_{5}$ fertilization of Nigella sativa plants. Rana (2012) also ensured these findings. This increasing may be explained due to that phosphorus known to help developing broader root system and thus helping the plants to extract water and nutrients from more depth. This, in turn, could enhance the plants to produce more assimilates which was reflected in high biomass (Gobarah et al., 2006). Researchers have been increasingly interested in using magnetic technology in agricultural fields after the positive effects of this technique on the growth and flowering of plants. This can be clear up that 
magnetized water has a positive effect on the characteristics of flowers, bulbs and seeds. This may be due to the physical and chemical changes of magnetically treated water, which resulted in the easy absorption of water and soluble elements by the root mass as well as improved vegetative growth characteristics resulting in an increase in the amount of photosynthesis (AlMu'adidi, 2006; Nasher, 2008.; Kuntyastuti and Suryantini, 2014.).

Table (12): Effect of magnetic water, humic acid and phosphor fertilizer on the total carbohydrates (\%) of Nigella sativus plant

\begin{tabular}{|c|c|c|c|c|c|c|}
\hline \multirow{2}{*}{$\begin{array}{c}\mathrm{P}_{2} \mathrm{O}_{5} \\
\left(\mathrm{mg} \cdot \text { pot }^{-1}\right)\end{array}$} & \multirow{2}{*}{$\begin{array}{l}\text { Magnetic } \\
\text { water } \\
\text { (hours) }\end{array}$} & \multicolumn{3}{|c|}{ Humic $\operatorname{acid}\left(\mathrm{mg} . \mathrm{L}^{-1}\right)$} & \multirow{2}{*}{$\begin{array}{c}\mathrm{P}_{2} \mathrm{O}_{5} \\
\times \\
\text { Magnetic } \\
\text { water }\end{array}$} & \multirow{2}{*}{$\begin{array}{l}\mathrm{P}_{2} \mathrm{O}_{5} \\
\text { effect }\end{array}$} \\
\hline & & 0 & 0.6 & 0.8 & & \\
\hline \multirow[t]{3}{*}{0} & 0 & $27.54 \mathrm{j}$ & $27.62 \mathrm{j}$ & $26.76 \mathrm{j}$ & $27.31 \mathrm{f}$ & \multirow[t]{3}{*}{$28.82 \mathrm{~b}$} \\
\hline & 12 & $29.37 f g$ & $29.06 \mathrm{~g}$ & $28.52 \mathrm{~h}$ & $28.98 \mathrm{~d}$ & \\
\hline & 24 & 30.03 ce & $30.46 b-d$ & $30.03 c-e$ & $30.17 \mathrm{a}$ & \\
\hline \multirow[t]{3}{*}{260} & 0 & $28.05 \mathrm{~h}-\mathrm{j}$ & $28.12 \mathrm{~h}-\mathrm{j}$ & $27.88 \mathrm{hi}$ & $28.02 \mathrm{e}$ & \multirow[t]{3}{*}{$29.53 \mathrm{a}$} \\
\hline & 12 & $29.87 d-f$ & $29.56 \mathrm{e}-\mathrm{g}$ & 29.64 e-g & $29.69 \mathrm{~b}$ & \\
\hline & 24 & $30.53 b c$ & $30.96 \mathrm{ab}$ & $31.16 \mathrm{a}$ & $30.88 \mathrm{a}$ & \\
\hline \multirow[t]{3}{*}{520} & 0 & $28.27 \mathrm{hi}$ & $28.30 \mathrm{hi}$ & $28.07 \mathrm{~h}-\mathrm{j}$ & $28.22 \mathrm{e}$ & \multirow[t]{3}{*}{$29.73 \mathrm{a}$} \\
\hline & 12 & $30.10 c-e$ & 29.74d-f & $29.83 \mathrm{ef}$ & $29.89 \mathrm{~b}$ & \\
\hline & 24 & $30.76 a b$ & $31.14 \mathrm{a}$ & $31.34 \mathrm{a}$ & $31.08 \mathrm{a}$ & \\
\hline \multirow{3}{*}{$\begin{array}{c}\mathrm{P}_{2} \mathrm{O}_{5} \\
\times \underset{\text { acid }}{\mathrm{Humic}}\end{array}$} & 0 & $28.98 b$ & $29.04 \mathrm{~b}$ & $28.43 c$ & \multirow{3}{*}{\multicolumn{2}{|c|}{$\begin{array}{c}\text { Magnetic water } \\
\text { effect }\end{array}$}} \\
\hline & 260 & $29.48 \mathrm{a}$ & $29.55 \mathrm{a}$ & $29.56 \mathrm{a}$ & & \\
\hline & 520 & $29.71 \mathrm{a}$ & $29.73 \mathrm{a}$ & $29.75 \mathrm{a}$ & & \\
\hline \multirow{3}{*}{$\begin{array}{l}\text { Magnetic } \\
\text { water } \\
\times \text { Humic } \\
\text { acid }\end{array}$} & 0 & $27.95 \mathrm{e}$ & $28.01 \mathrm{~d}$ & $27.57 \mathrm{e}$ & \multicolumn{2}{|c|}{$27.85 \mathrm{c}$} \\
\hline & 12 & $29.78 \mathrm{bc}$ & $29.45 \mathrm{bc}$ & $29.33 c$ & \multicolumn{2}{|c|}{$29.52 b$} \\
\hline & 24 & $30.44 \mathrm{a}$ & $30.85 \mathrm{a}$ & $30.84 \mathrm{a}$ & \multicolumn{2}{|c|}{$30.71 \mathrm{a}$} \\
\hline \multicolumn{2}{|c|}{ Humic acid effect } & $29.39 \mathrm{a}$ & $29.44 \mathrm{a}$ & $29.25 \mathrm{a}$ & & \\
\hline
\end{tabular}

*Means followed by the same letter for each factor and interaction do not differ significantly from each other's according to Duncan's Multiple range Test at 5\% level.

The same results also obtained by Amin (2009) found that irrigating Iris bulbs with magnetically treated water resulted in an increase in stem diameter, chlorophyll and dry weight Al-Jubouri (2006) approved that by improving the flowering characters of Tagets erecta $\mathrm{L}$ when irrigated by magnetized water. Deshpande (2014) conferred that using the magnetic water in place of normal tap water can be seen as a promising technique for rapid and healthy growth of plants. Regarding to the humic acid it works indirectly on the speed of absorption and transfer of the rest of the elements by entering the formation of chlorophyll pigments, thus increasing the carbonation process and building the proteins of great importance in stimulating plant growth and reaching a good nutritional state, which increased the efficiency of the plant to absorb 
and accumulate the elements, (Taiz and Zeiger, 2006; David et al.,1994) have reported that humic substances promoted growth and more mineral nutrient uptake of plant due to the better-developed root systems. Although there were no significant increscent in the studied objective may be due to the shortage of concentrations that used in this trail, except the volatile oil percentage these results agreed with Noroozi sharaf and Kaviani (2018) when they studied the effect of humic acid concentrations on Thymus vulgaris they concluded that humic acid increased the essential oil quality and quantity by increasing the humic acid concentrations. Humic acid is natural biological organic, which has a high effect on plant growth and quality. However, the mechanisms of the promoting effect of humic acid on the volatile composition were rarely reported. In this study, the effects of soil application of humic acid on the chemical composition and nutrients uptake of Thymus vulgaris were Nardi et al. (2002) proposed that humic acid could directly influence plant growth components such as cell permeability, respiration, photosynthesis, and cell elongation. Previous researches have shown other effects of humic substances on fruits (Arancon et al. 2006) vegetables (Yildirim 2007), cereals (Jones et al. 2007) and Lolium perennial (Verlinden et al. 2010). This was followed by reduceing in the incidence of plant disease (Naidu et al. 2013; Olivares et al. 2015). In addition to the notable changes on nutrient uptake and plant primary metabolism, secondary metabolism may also be strongly affected by humic substances (Canellas et al. 2015).

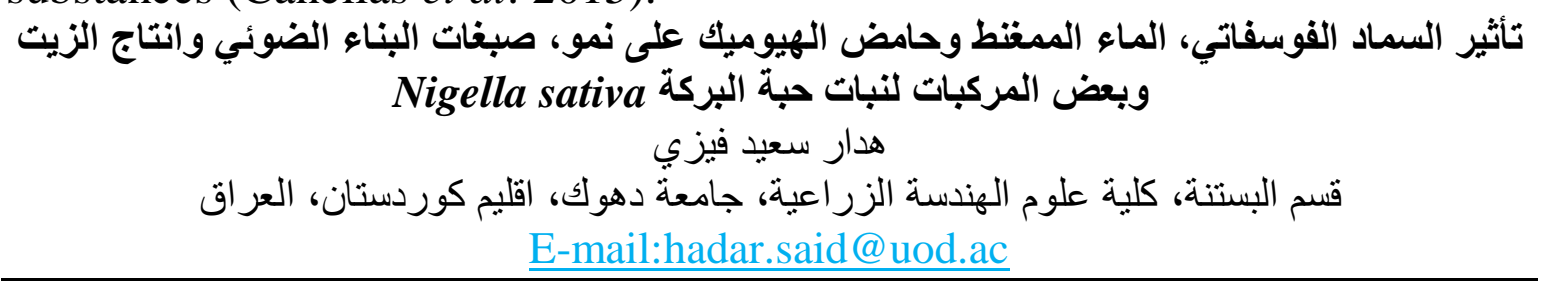

الخلاصة

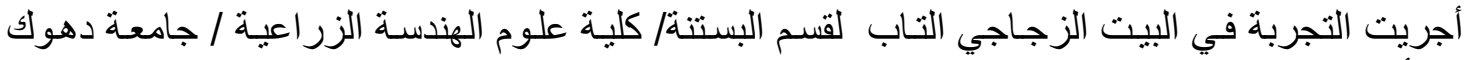

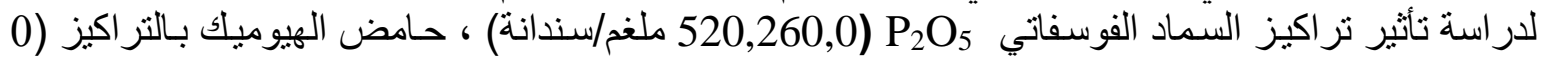

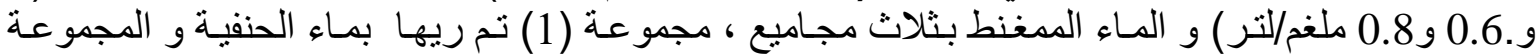

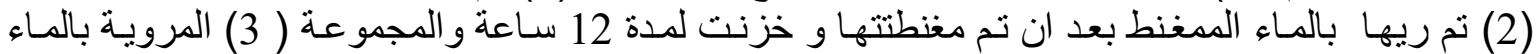

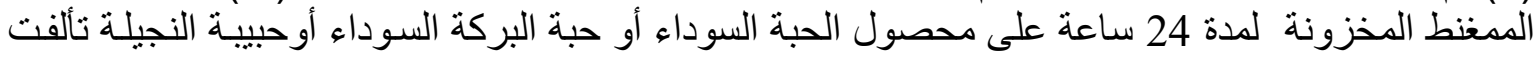

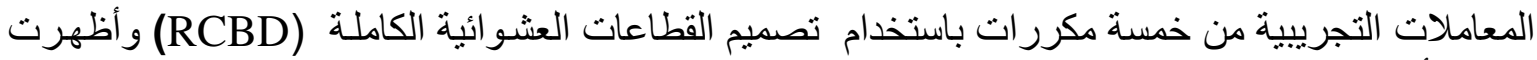

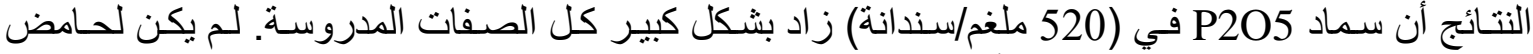

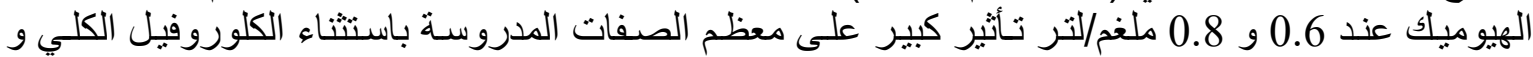

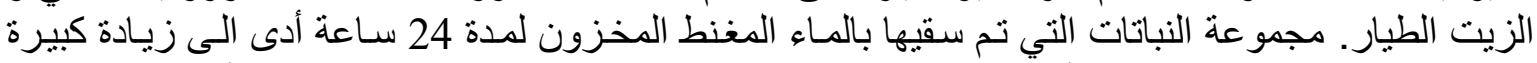

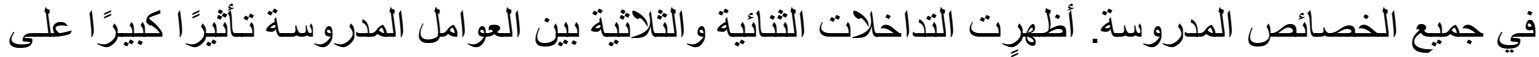

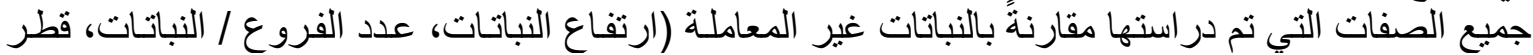

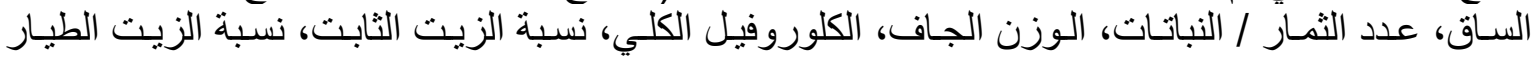

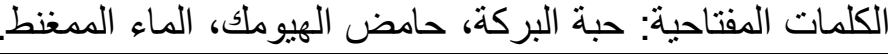
تاريخ تسليم البحث: 2019/3/19 تاريخ قبول البرلئ البحث: 2019/10/10 


\section{REFERENCES}

Anonymous. (2000). Official Method of Analysis $11^{\text {th }}$ edition Washington D.C. Association of Official Analysis Chemist. P. 1015.

Al- Jubouri,I.R. (2006). Effect of Spraying On Liquid Fertilizer, Water Type, Date Of Planting In Vegetative And Syphilis Growth, And Production of Some Carotenoids of Tagestes erecta L.plant. Master of Agriculture, University of Baghdad. (In Arabic).

Al -Rubaye, B. J. (2009). Effect of phosphorus and sulphur fertilizers on some yield components and oil content of black cumin (Nigella sativa L.) Seeds. Basrah Journal of Agricultural Sciences. 22(2): 155-165.

Aladjadjiyan, A., (2010). Influence of stationary magnetic field on lentil seeds Journal of International Agro physics. (24):321-324.

Al-Mu'adidi ,A.F.Q. (2006). Effect of Magnetic Technology in Some Ornamental Plants. PhD thesis- Faculty of Agriculture - University of Baghdad. (In Arabic).

Ameen,S.K.M.(2009). Influence of paclobutrazol and magnetic water on growth, flowering, and bulblets production of iris hollandica. Diala, Journal.(36):2009.203-215. and Applied Sciences. 5 (9): 1503-1509 and Applied Sciences. 5 (9): 1503-1509 and Applied Sciences. 5 (9): 15031509

Arancon, N.Q.; C.A .Edwards, S. Lee and R .Byrne. (2006). Effects of humic acids from vermicomposts on plant growth. European Journal Soil Biology (42): 65-69.

Buriro, M. A. and M. Tayyab. (2007). Effect of nigella sativa on lipid profile in albino rats. Gomal Journal of Medical sciences 5(1): 10-15.

Canellas, L.P.; F.L. Olivares, N.O. Aguiar, D.L. Jones, A. Nebbioso, P. Mazzei and A. Piccolo .(2015). Humic and fulvic acids as biostimulants in horticulture. Journal of Horticulture Science. (196):15-27.

Dastgheib, A.; M. Z. Buntat and S. M. Zafar Iqbal, (2013). Advanced Science Letters. (19):2523-2527.

David, P.P.; P.V. Nelson and D.C. Sanders. (1994). A humic acid improves growth of tomato seedling in solution culture. Journal of Plant Nutrition. (17): 173-184.

Deshpande, M. (2014). Effect of magnetic water on growth of legumes. european Journal of Applied Engineering and Scientific Research. (3)3- 12.

Fard , B. M.; M . Khoshravesh and M.. S. Kiani.(2011). Effects of magnetized water on soil chemical components underneath trickle irrigation Journal of Irrigation and Drainage Engineering .137 (6):398-402.

Gad El-Hak, S.H.; A.M. Ahmed, and Y.M.M. Moustafa. (2012). Effect of foliar application with two antioxidants and humic acid on growth, yield and yield components of peas (Pisum Sativum L.). Journal of Horticultural Science \& Ornamental Plants. 4 (3): 318-328.

Garg, V. K. and S. Malhotra, (2008). Response of Nigella Sativa L. to fertilizers under sodic soil conditions. Journal of Medicinal and Aromatic Plant Sciences. 30: (2):122-125. 
Ggrainger H. F.P.S. (1968) .The british pharmacopoeia. Journal of Pharmacy and Pharmacology. 21( 2): 132-134.

Gharby, S., H. Harhar., D. Guillaume., A. Roudani., S. Boulbaroud., M. Ibrahimi., M. Ahmad., S. Sultana., T. BenHadda., I. Chafchaouni. and Z. Charrouf.(2014). Chemical investigation of Nigella sativaL. seed oil produced in morocco. Journal of the Saudi Society of Agriculture Sciences.14.(2):172-177.

Gobarah, M. E.,; M. H. Mohamed and M.M. Tawfik (2006). Effect of phosphorus fertilizer and foliar spraying with zinc on growth, yield and quality of groundnut under reclaimed sandy soils. Journal of Applied Science Research 2(8): 491-496.

Grewal, H .S. and B. L. Maheshwari (2011). Magnetic treatment of irrigation water and snow pea and chickpea seeds enhances early growth and nutrient contents of seedlings Journal of Bioelectro-magnetics. (32): 58-65.

Hameda, El. and S. A. El Sayed, (2014). Application of exogenous ascorbic acid on tomato (Solanum lycopersicum L.) seeds under $\mathrm{NaCl}$ salinity stress. American Journal of Experimental Agriculture. 4 (4):476-496.

Hammo ,Y. H.( 2008).Effect of high levels of nitrogen and phospours fertilizer, pinching, and seed rate on growth and yield componentes of Nigella sativa L. 1-vegetative growth and seed yield .Mesopotamia Journal. of Agriculture. 36 (1):1-12.

Herbert, D.; P.p.J.Phipps and R.E.Strange. (1971).Chapter III Chemical Analysis of Microbial Cell.

Hossein zadeh, H; S. Parvardeh, M. N. Asl., H. R. Sadeghnia and T. Ziaee. (2007). Effect of thymoquinone and nigella sativa seeds oil on lipid peroxidation level during global cerebral ischemiare perfusion injury in rat hippocampus. Journal of Phytomedicine, 14(9): 621-627.

Kamil, Z.H. (2003). Spectacular black seeds (Nigella sativa) medical importance review. Medical Journal of Babylon. 10 (4): 1-9

Kuntyastuti, H. and S.Suryantini (2014). Effect of phosphorus fertilization on soil phosphrous level, growth and yield of soybean (Glycin max 1.) in paddy soil. Journal of Experimental Biology and Agricultural Sciences. 3(1):1-9.

Lam, M. (2001). "Magnetized Water". (www.DrLam.com).

Leonard, A.G. (2008). Humic Acid: 100\% Natural, Many Uses. Golden Harrest Organic .LLCTM.

Maheshwari, B. L. and H. S. Grewal. (2010). Magnetic treatment of irrigation water and snow pea and chickpea seeds enhances early growth and nutrient contents of seedlings. Agricultural Water Management. (96): 1229-1236.

Mousavi, S. R. (2011). Zinc in Crop Production and Interaction with Phosphorus. Australian Journal of Basic

Mousavi, S. R. (2011). Zinc in Crop Production and Interaction with Phosphorus. Australian Journal of Basic

Mousavi, S. R. (2011). Zinc in Crop Production and Interaction with Phosphorus. Australian Journal of Basic 
Mousavi,S.R. (2011).Zinc in crop production and interaction with phosphor .Australian Journal of Basic and Applied Science.5(9):1503-1509.

Naidu Y, Meon S, Siddiqui Y (2013) Foliar application of microbialenriched compost tea enhances growth, yield and quality of muskmelon (Cucumis melo L.) cultivated under fertigation system. Journal of Horticulture Science.(159):33-40.

Nardi S, Pizzeghello D, Muscolo A, Vianello A (2002). Physiological effects of humic substances on higher plants. Journal of Soil Biology Biochem .(34):1527-1536.

Nasher, S.H. (2008). The effect of magnetic water on growth of chick-pea seeds. Journal of Engineering \& Technology. 26(9): 1-3.

Nickavar, B.; F. Mojab, K. Javidnia and M. R Amoli. (2003). Chemical composition of the fixed andvolatile oils of Nigella sativa L. from Iran. Zeitschrift Fur Naturforschung Conference, 58(9/10): 629-631.

Noroozi sharaf, A. and M. Kaviani.(2018). Effect of soil application of humic acid on nutrients uptake, essential oil and chemical compositions of garden thyme (Thymus Vulgaris L.) under greenhouse conditions. Physiology Molecular Biology Plants journal .24(3):423-431.

Olivares, F.L.; N.O. Aguiar, R.C.C.Rosa and L.P. Canellas. (2015). Substrate biofortification in combination with foliar sprays of plant growth promoting bacteria and humic substances boosts production of organic tomatoes. Journal of Horticulture Science. (183):100-108.

Rana ,S.(2012). Effect of Nitrogen and Phosphorus on growth, yield and quality of Black Cumin (Nigella sativa L.). Master thesis. College of Horticulture. Mandsaur university.

Ranganna S. (1986). Handbook of analysis and quality control for fruit and vegetable products. Tata McGraw-Hill Publishing Company, New Delhi, India. 124-125.

Riaz, M; M. Syed and F. M. Chaudhary. (1996). Chemistry of the medicinal plants of the genus Nigella. Journal of Hamdard Medical .( 39): 40-45.

SAS Institute, Inc (2007). Statistical Analysis System. SAS institute Inc., Cary, NC. USA.

Shabnam, J.; A. A. Shahid, M. S. Haider, A. Umeera, R. Ahmad and S. Mushtaq. (2012). Nutritional, phytochemical potential and pharmacological evaluation of nigella sativa (kalonji) and trachyspermum ammi (Ajwain). Journal of Medicinal Plants Research. 6(5): 768-775.

Singh, S. K.; S. Sardar and S. Singh (1999). Response of nigella (Nigella sativa) to nitrogen and phosphorous crop. Journal of Hisar Research. 18 (3). (C. F. CAB Abstracts 1998 / 08 - 2000/04).

Taiz, L. and E. Zeiger. (2006). Plant Physiology. Fourth Edition Sinauer Assotiates, Inc., Publishers Sunderland, Massachusetts.

Ul-Hassan Gilani,A.; Q.Jaber and M.A.Ullahkhan.(2004). A review of medicinal uses and pharmacological activities of Nigella sativa. Pakistan Journal of Biological Sciences.7 (4):441-451. 
Verlinden G.; T. Coussens, A. De Vliegher, G. Baert and G. Haesaert. (2010). Effect of humic substances on nutrient uptake on production and nutritive value of herbage from sown grass pastures. Grass Forage Science Journal (65):133-144

Yildirim E. (2007) .Foliar and soil fertilization of humic acid affect productivity and quality of tomato. Acta Agriculture Scanned Sect B .Soil Plant Science journal (57): $182-186$ 